\title{
PENSANDO A FOTOETNOGRAFIA: UMA ANÁLISE DA EXPERIÊNCIA \\ DA OFICINA DE COMPOSTAGEM REALIZADA EM IRANDUBA/AM \\ PELO PROJETO REVOLUÇÃO DOS BALDINHOS, DE FLORIANÓPOLIS/SC
}

Adriana Eidt ${ }^{1}$

O presente artigo é resultado de uma etnografia realizada durante uma pesquisa no projeto intitulado "Avaliação de Tecnologia Social - O Programa Revolução dos Baldinhos e a replicação da gestão comunitária de resíduos orgânicos em comunidades de Florianópolis e Iranduba (AM)", aprovada pelo programa CNPq/MCTIC/MDS no. 36/2018, vigente de março de 2019 até dezembro de 2020. Esse projeto teve como intuito a avaliação da ampliação/replicação do modelo de Tecnologia Social de gestão comunitária de resíduos orgânicos do Projeto Revolução dos Baldinhos (PRB), que é desenvolvido na comunidade Chico Mendes, em Florianópolis ${ }^{2}$.como resposta aos casos de doenças erradicadas pelo descarte indevido do lixo, pois houveram casos de leptospirose na comunidade, causando mortes. Uma das soluções para esse problema foi pensar o gerenciamento de resíduos orgânicos, pelo método de compostagem termofílica ${ }^{3}$, pois antes esses resíduos eram depositados nas ruas e assim atraiam os ratos e, por conseguinte, algumas doenças. Para fazer esse gerenciamento, as moradias participantes recebem um baldinho para armazenar o material orgânico descartado. O processo de coleta dos resíduos é realizado nos Pontos de Entrega Voluntária (PEVs) por membros da comunidade, estes que também são responsáveis pelo gerenciamento posterior, no pátio de compostagem, onde esse resíduo é transformado em adubo e distribuído entre os moradores. O excedente fica disponível à venda, gerando parte da renda do projeto. Nos pátios de compostagem, distribuídos em diferentes pontos da comunidade ${ }^{4}$, são construídas as leiras: canteiros onde é condicionado o material orgânico recolhido. Participam, ao todo, 150 famílias. Entre os

\footnotetext{
${ }^{1}$ Universidade Federal de Pernambuco, Brasil. Email: drikamixer@gmail.com ORCID ID: https://orcid.org/0000-0003-1383-6272

${ }^{2}$ Sobre o projeto Revolução dos Baldinhos e sua atuação na cidade de Florianópolis, temos outro artigo nesse mesmo volume.

${ }^{3}$ Compostagem é o conjunto de técnicas aplicadas para estimular a decomposição de materiais orgânicos por organismos heterótrofos aeróbios, com a finalidade de obter, no menor tempo possível, um material estável.

${ }^{4}$ Além do pátio principal, situado na Escola de Educação Básica América Dutra Machado, eventualmente são montados canteiros próximo a sede do PRB.
} 
objetivos levantados na avaliação está a análise do processo de sensibilização ${ }^{5}$ dos moradores. Para desenvolver essa pesquisa foi utilizado o método etnográfico de observação participante e de descrição densa (Geertz, apud Rial, 2018) das experiências obtidas em trabalho de campo. Participaram nesse projeto a equipe da Universidade Federal de Santa Catarina (UFSC) em Florianópolis, composta pela professora Dra. Carmen Silvia Rial, coordenadora, a pós-doutoranda Caroline Soares de Almeida, subcoordenadora, a estudante de graduação em Ciências Sociais Amanda Bouvié, as estudantes de graduação em Antropologia Adriana Eidt e Caroline Mariga; a equipe da Universidade Federal do Amazonas (UFAM) em Manaus composta pela professora Dra. Márcia Regina Calderipe Farias Rufino, coordenadora da equipe, as doutorandas em Antropologia Lourdes de Fátima Moraes de Sousa Saldanha e Camila Garcia Iribarrem, e a mestranda em Antropologia Samile Magalhães Pereira; como colabora técnica da Revolução dos Baldinhos, a coordenadora Cintia Aldaci da Cruz. A principal discussão deste artigo refere-se ao uso dos recursos audiovisuais em trabalho de campo, focando principalmente no uso da fotografia, uma vez que essa abordagem esteve presente durante todo campo da pesquisa, seja em Florianópolis ou Iranduba. Assim: "Entendendo-se aqui por antropologia visual o estudo das significações de imagens singulares sobre a diversidade cultural, que transportam as representações sociais para os suportes fotográficos e filmográficos.” (Campos, 1996)

Então, ao fazer o acompanhamento fotográfico de uma etnografia, ou fotoetnográfico $^{6}$, requer pensar em questões tanto de imagens como do campo etnográfico, estudados pela Antropologia. Para Achutti (1997) "sendo a fotografia um permanente ato de recortar e enquadrar elementos da realidade num plano - duas dimensões - faz se necessário um domínio técnico específico. E o autor segue, pois esse "domínio técnico aliado ao olhar treinado do antropólogo pode levar a construção de um trabalho fotoetnográfico que venha ser relevante, não só mais como uma das técnicas de pesquisa, mas também como outra forma de narrativa”. Assim, muitas questões são levantadas antes de adentrar o campo: Sobre o uso da fotografia numa etnografia, o quanto é importante o conhecimento das técnicas fotográficas e etnográficas, e suas possibilidades e obstáculos.

\footnotetext{
${ }^{5}$ A sensibilização é realizada por agentes comunitários voluntários que fazem visitas periódicas nas casas da comunidade. Busca-se, assim, identificar as demandas e compreender as lógicas e morais que permeiam as noções de afeto e solidariedade locais. A partir desse reconhecimento é que os voluntários introduzem a educação ambiental

${ }^{6}$ Uma forma específica de fotografia informada pelo saber antropológico e, por decorrência, empenhada no inventário dos elementos culturais e sociais de grupos humanos. (Achutti, 1996)
} 
Partindo do objetivo de analisar os processos que envolvem a fotoetnografia, o trabalho divide-se em duas partes. Na primeira é exposta o trabalho fotoetnográfico realizado durante o campo em Iranduba. Na segunda parte são discutidas questões do uso da fotografia em campo e outras que vem à tona antes e durante o trabalho de campo.

A etnografia aqui exposta foi realizada durante uma viagem para Iranduba , que fica localizada a $34 \mathrm{~km}$ de Manaus, com a população que gira em torno de 48.296 habitantes distribuídos numa área de $2.216,817 \mathrm{~km} 2$ e, no estado do Amazonas. O município abrange quatro zonas distritais, entre elas, o distrito do Lago do Limão. Esse distrito possui uma população estimada em mil moradores, ocupando parte de uma Área de Preservação Ambiental. A Vila do Lago do Limão, sede administrativa distrital, conta com uma escola municipal e um posto de saúde. O intuito dessa viagem era de acompanhar a realização de uma formação em reciclagem de resíduos orgânicos no distrito do Lago do Limão, para que no final fosse montada uma composteira naquela comunidade. A coleta de lixo no Lago do Limão é realizada pela Prefeitura de Iranduba, uma vez a cada oito dias, gerando grandes problemas no gerenciamento dos resíduos sólidos, pois o plano da prefeitura atinge apenas quatro pontos - três escolas e uma paróquia - da região central do município. Nessas condições, a prática da queima do lixo domiciliar é muito comum. Além disso, existe o agravante do aterro sanitário, que atende a demanda de toda a cidade, estar em situação irregular, conforme atestado pela Secretaria de Estado de Meio Ambiente (SEMA), em função do sobrecarregamento residual e do grande impacto ambiental causado pela poluição do solo e das águas do entorno. (Rial, 2018)

Cabe salientar que parte do grupo atuante nesse projeto, composta por pesquisadoras da Universidade Federal do Amazonas ${ }^{7}$ já vinha realizando trabalho de campo no local, tendo discutido com alguns moradores para o melhor local para realizar a oficina - e, por conseguinte, construir a composteira. $\mathrm{O}$ relato que segue conta um pouco a história dessa viagem antropológica.

\section{OFICINA EM IRANDUBA : PRIMEIRO DIA}

\footnotetext{
${ }^{7}$ A equipe da UFAM é coordenada pela professora Dra. Márcia Regina Calderipe Rufino e as doutorandas do Programa de Pós-Graduação em Antropologia Social Camila Garcia Iribarrem e Lourdes de Fátima Moraes de Sousa Saldanha.
} 
Na manhã do dia 30 de agosto saímos de Manaus e seguimos para Iranduba, região metropolitana. Estávamos com previsão de chegar às 9 horas, mas pegamos um trânsito muito intenso dentro da cidade ${ }^{8}$. Chegamos com certo atraso, e os alunos da escola Chico Mendes (anteriormente chamada de Professora Maria Auxiliadora Mesquita Simas, como mostra a figura 2) já nos aguardavam. Por causa da pressa, fiz imagens de vídeo e duas fotografias rapidamente antes de entrar na escola. Depois, verificando essas imagens, percebi que as primeiras eram da rua onde estava a escola (Fig. 1), e da fachada da escola (Fig.2).

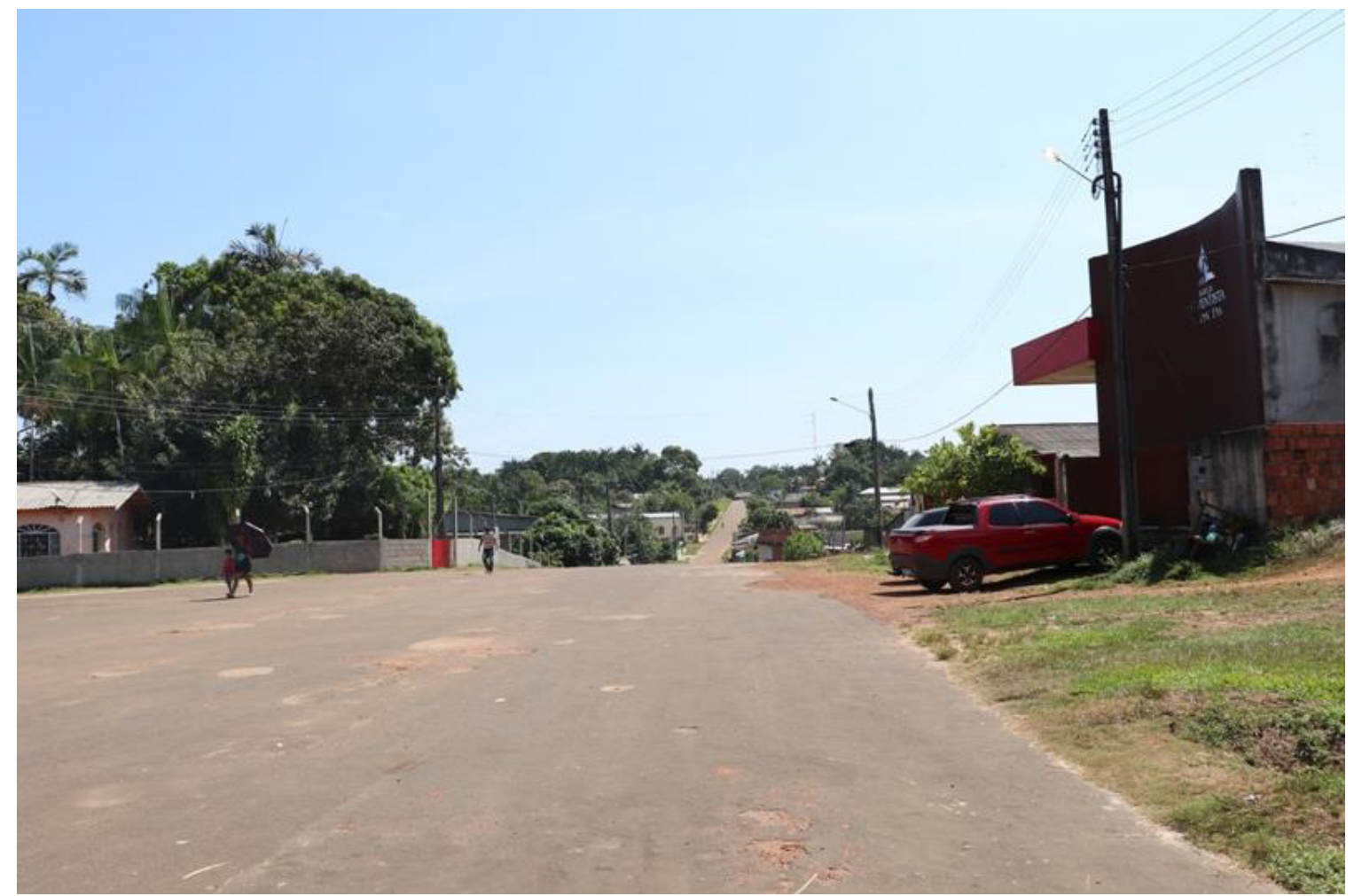

Fig. 1: Lago do Limão

\footnotetext{
${ }^{8} \mathrm{O}$ trânsito na cidade de Manaus é bastante carregado e imprevisível. Um trajeto de poucos quilômetros, em um horário de pico, pode demorar horas
} 


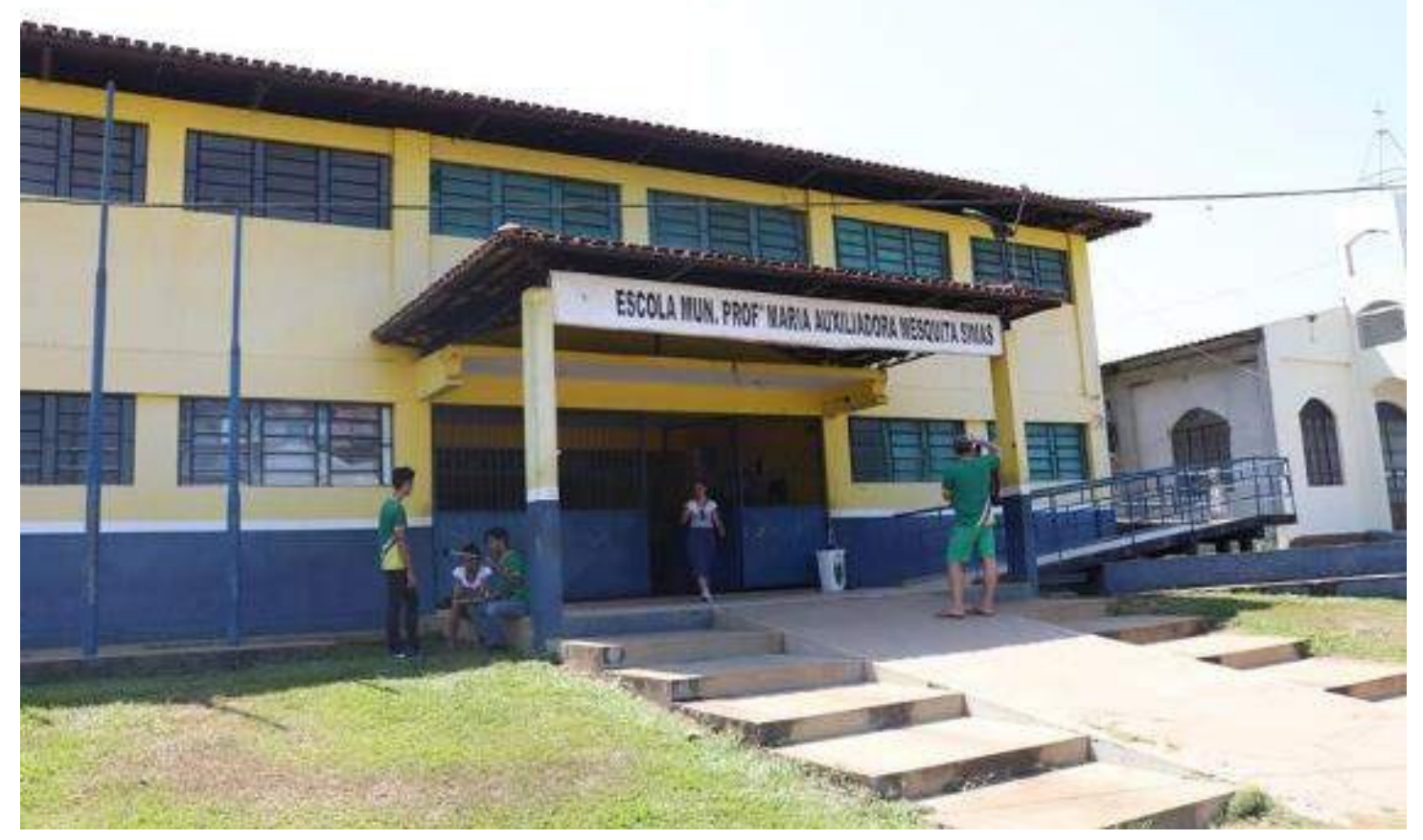

Fig. 2: Fachada da escola

A fotografia 1 mostra a visão do caminho que tínhamos percorrido para chegar até ali. Não chega a ser uma foto aérea, a qual permitiria visualizar uma área maios extensa e entender um pouco melhor o bairro onde se localiza a escola que iriamos visitar. Porém, como foi feita de um ponto mais elevado, consegue-se ainda assim ter uma visão da estrada/rua por uma distancia de quase um quilometro, perceber-se a baixa densidade populacional do bairro (são cerca de 15 casas, separadas uma das outras, são poucas pessoas na rua) e o quanto ele é arborizado. Se usamos o recurso de amplia-la, outras informações ainda podem ser observadas: a vegetação é variada, inclui na casa mais rosa algum tipo de palmeira (açaí? Palmito? Coqueiro?) com 4 exemplares, uma planta ornamental em frente, além de arvores bastante frondosas que proporcionam um sombra bastante densa. A casa, que vemos com mais precisão na foto, me leva a pensar tratar-se de uma camada média: tem muro sem pintura que é completado em cima por uma cerca de metal, apoiada em postes de cimento, tem uma ampla janela protegida por grade de metal decorada e uma antena parabólica. Em frente à escola, apenas dois carros, um sendo utilitário.

Como é comum no Brasil, a eletricidade é distribuída por fios aéreos - eles correm paralelamente à estrada/rua e alguns a cruzam. A estrada é relativamente bem 
conservada, com alguns remendos na terra batida. Vemos três pessoas na foto, uma mulher (imagino, pois está usando saia e tem os cabelos compridos, roupa e cabelo mais comum entre as mulheres, além do modo de andar com as pernas mais próximas), uma criança e um homem (imagino, pela roupa e cabelo curto, além do modo de andar, com pernas mais afastadas), e imaginamos que o ponto mais distante seja uma quarta pessoa, cujo gênero é impossível de determinar. A mulher leva pela mão uma criança, e se protege do sol com uma sombrinha - num calor de aproximadamente 40 graus, a mulher se protege e protege um pouco a criança, o homem, não. A ausência de pessoas na estrada pode ser devido ao calor, me indago.

Pela pressa, não consegui captar todo panorama, mas observando esse trecho já é perceptível muito do ambiente. Assim, compartilho da mesma ideia que esta passagem de Carmen Rial (2001):

\begin{abstract}
As fotos aéreas ou os planos panorâmicos, como já ensinava Collier Jr, são excelentes instrumentos de entrada no primeiro momento em campo que é marcado pela exploração inicial. São como um tatear no escuro inicial. Servem para uma primeira abordagem do terreno, servem para que se visualize o todo, os seus contornos gerais. Servem como mapas que nos localizam no campo a ser estudado. (Rial, 2001)
\end{abstract}

A direção da escola, que já tinha sido previamente contata pela equipe do projeto de Manaus, demonstrou-se bastante receptiva aceitando a proposta de sediar a composteira piloto no Lago do Limão. A ideia era que, com o tempo, outras composteiras fossem montadas em diferentes pontos da comunidade. A escola fica em um distrito com população de baixa renda (Lopes; Nogueira; Nascimento, 2011), enquadrado entre os "territórios prioritários" pelo então Ministério do Desenvolvimento Social, sendo essa uma das razões de ter sido escolhida como o local para a replicação da Tecnologia Social (TS) de gestão comunitária de resíduos orgânicos, no modelo do Projeto Revolução dos Baldinhos.

Eu já tinha acompanhado algumas dessas oficinas em Florianópolis, e tinha

\footnotetext{
${ }^{9}$ Os Territórios Prioritários consistem em localidades de baixo Índice de Desenvolvimento Humano (IDH) incluídos na lista do PROGREDIR, programa lançado pelo então Ministério do Desenvolvimento Social (hoje reduzido à Secretaria do Desenvolvimento Social, ligada ao Ministério da Cidadania) que visa ações do governo federal para promover a autonomia, por meio da geração de emprego e renda, das famílias inscritas no Cadastro Único para Programas Sociais do Governo Federal e beneficiárias do Programa Bolsa Família. O projeto Avaliação de Tecnologia Social - O Programa Revolução dos Baldinhos e a replicação da gestão comunitária de resíduos orgânicos em comunidades de Florianópolis e Iranduba (AM) é parte subsidiado por esse programa através do CNPq/MCTI
} 
uma pequena ideia do que seria apresentado para os alunos e os professores da escola amazonense. Ainda assim, houve aquele momento inicial de estranhamento da antropóloga no campo, então com mais calma passei a observar os detalhes do local, esse sim desconhecido para mim. Iranduba, localizada a $34 \mathrm{~km}$ de Manaus,tem às suas margens os rios Solimões (figura 3) e Negro. Desde a inauguração da ponte Jornalista Phelippe Daou que liga as cidades de Manaus e de Iranduba, sobre o Rio Negro, o cenário populacional do Lago do Limão tem sofrido mudanças com a vinda de moradores oriundos de outras regiões do estado do a Amazonas, sobretudo da capital em busca de tranquilidade e custo de vida mais barato (Pereira; Wiggers, 2018).

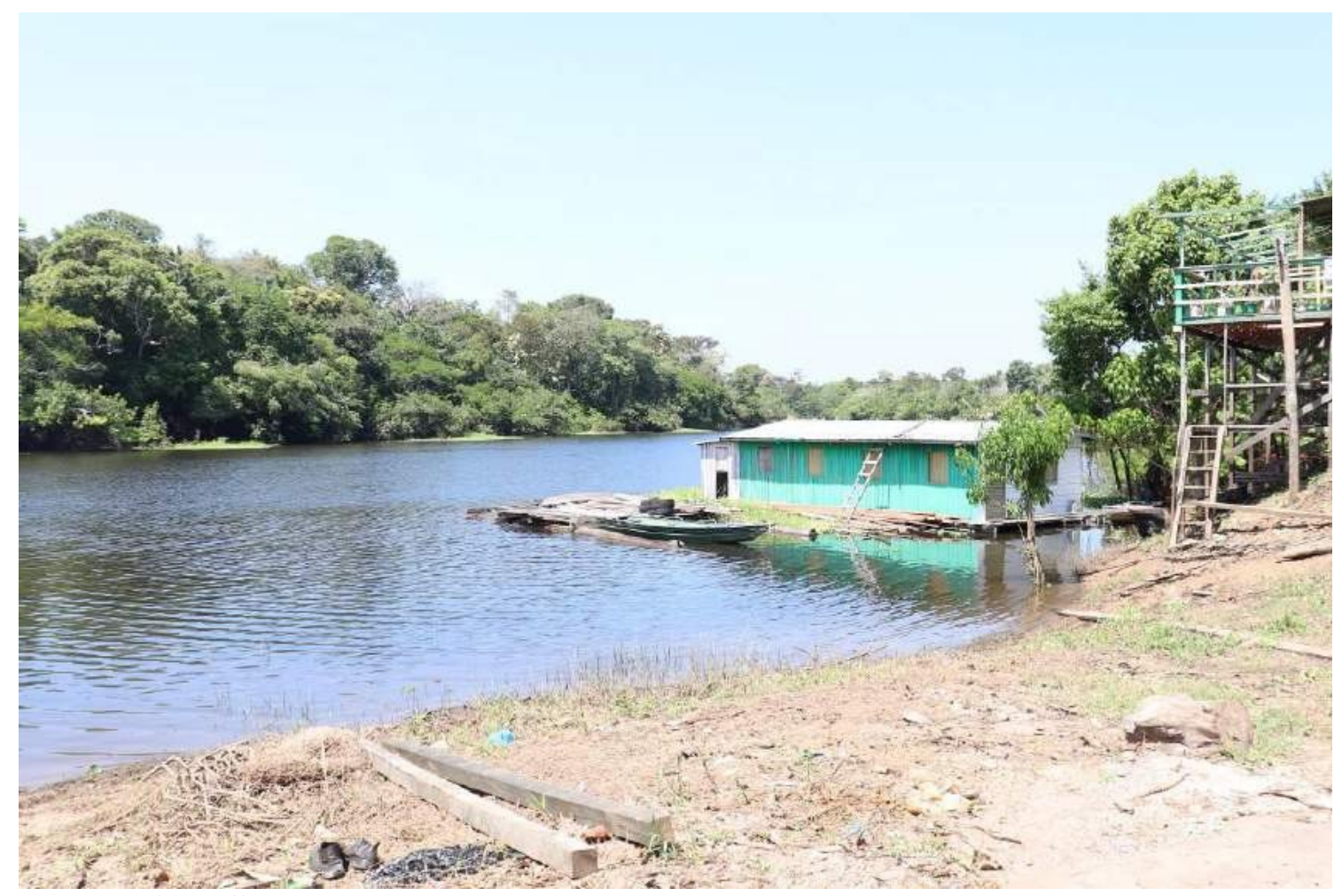

Fig. 3: Rio Solimões

Entramos na escola e logo Cíntia começou a conversar com os estudantes, falou sobre o Projeto Revolução dos Baldinhos, explicou do que se tratava, explicou o que era compostagem, e procurou fazer a sensibilização dos jovens sobre a importância da separação dos resíduos. Enquanto isso, eu desenvolvia meu trabalho fotográfico e de filmagem, sempre tomando cuidado, pois anteriormente fui alertada pela colega Caroline que, por questões éticas, já que se tratava de uma população vulnerável, não poderia filmar e nem fotografar as crianças. Esse foi meu maior desafio na captação 
das imagens, pois os alunos eram o maior público. Para isso eu tinha que mudar os planos de captação para que pudesse inserir a presença deles, sem necessariamente incluir suas imagens de rosto. Optei por fazer planos gerais, como esse:

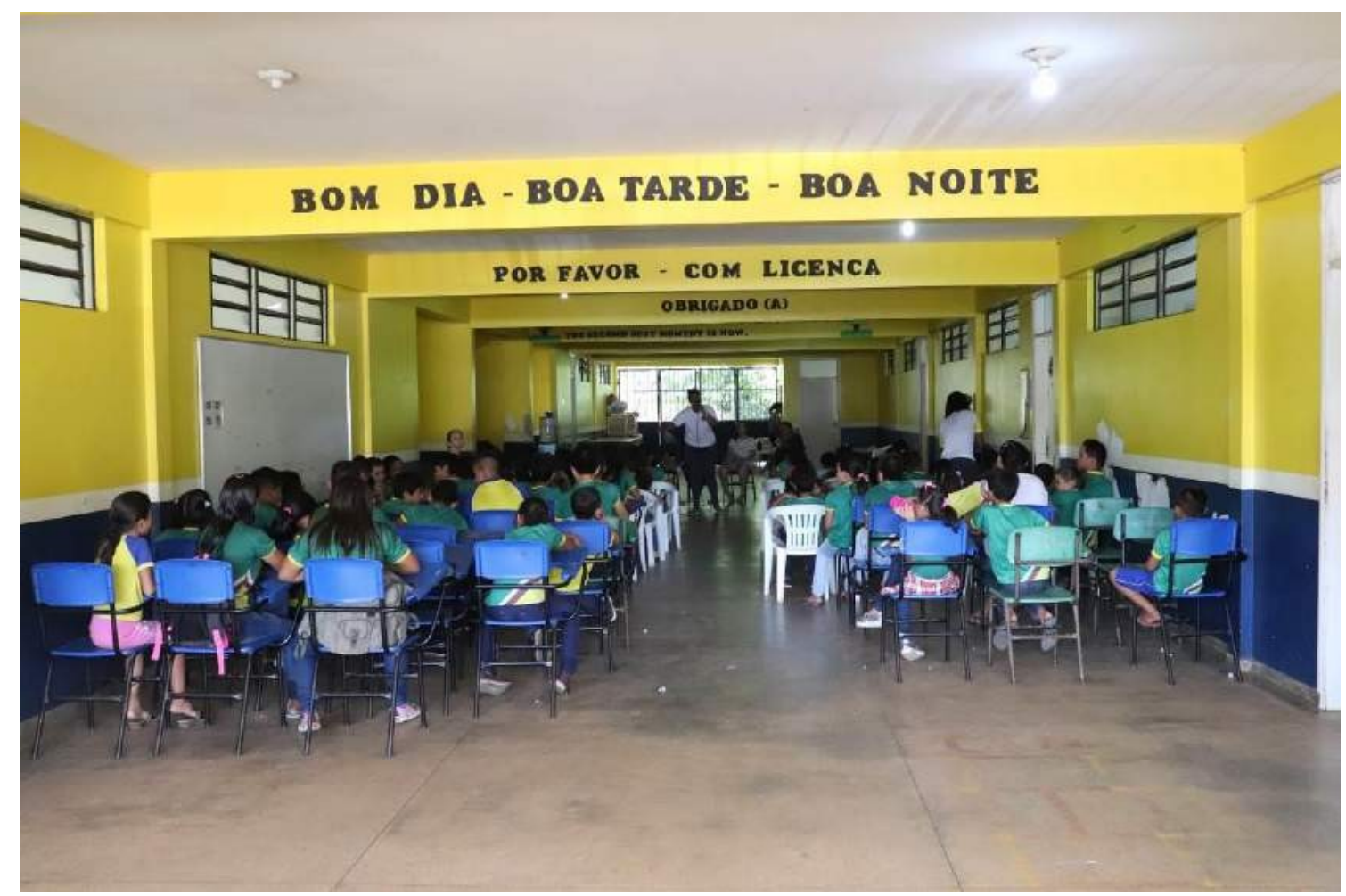

Fig. 4: Palestra no período da manhã

Após a palestra, que acabou perto do meio - dia, pudemos conhecer as pessoas que estavam trabalhando na escola, as colegas do projeto conversaram com os funcionários ali presentes enquanto eu ajeitava os equipamentos. Demos uma volta caminhando ali por perto, pois era muito quente e não tínhamos como ir até muito longe. Fomos observar o rio. Aproveitamos para fazer um lanche e discutir sobre qual seria a melhor forma de fazer a composteira naquele local. Cintía foi ver um local atrás da escola, mas nesse terreno havia uma fossa ${ }^{10}$, o que poderia contaminar se optássemos pela construção da leira ${ }^{11}$ no chão, em contato com a terra. Havia outro terreno que

\footnotetext{
${ }^{10}$ Fossa é como se designa comumente as fossas sépticas, unidade de tratamento primário de esgoto domestico que separa os resíduos sólidos e líquidos. Muito utilizada também em Florianópolis, onde são poucas as áreas cobertas por esgoto e unidades de tratamento.

${ }^{11}$ Leira é como se designa tecnicamente as composteiras de chão, os locais onde são depositados os resíduos sólidos com a terra que os cobre. São pequenos montes (de uns 3 por 1 metro) em que o resíduo orgânico é deixado para sofrer o processo químico que o tornará em adubo - esse processo, em uma
} 
pertencia a Associação de Moradores, mas deveríamos falar com o responsável para saber se poderíamos usá-lo ou não. Descansamos um pouco e seguimos para a oficina da tarde, realizada no mesmo local da Oficina da manhã.

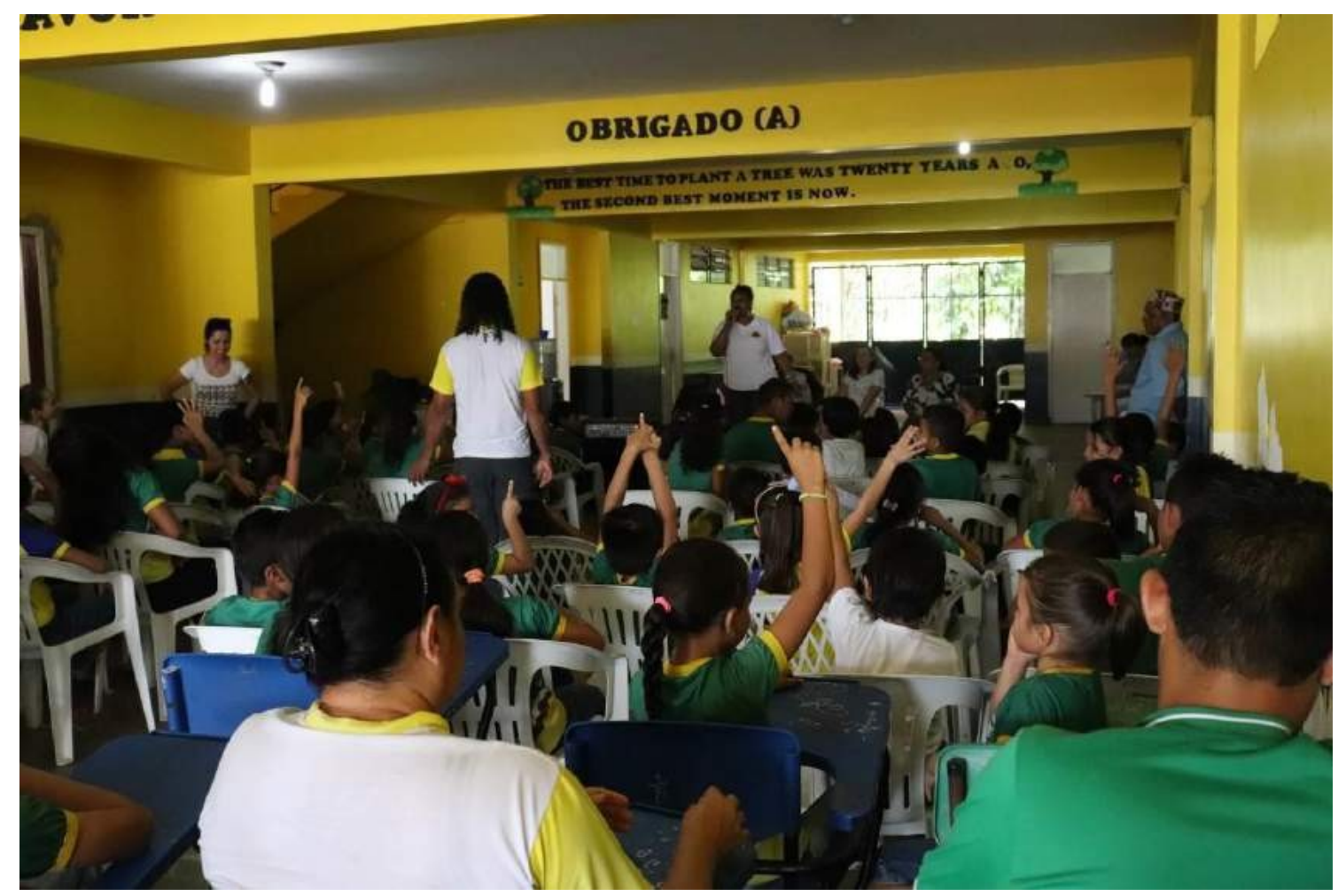

Fig. 5: Oficina no período da tarde

Cintia conversou com esse novo grupo, enquanto novamente eu fazia imagens. Muitas crianças se aproximavam para verificar como as imagens estavam sendo feitas, e eu explicava como funcionava a máquina fotográfica, tentando não desviar a atenção dessas crianças do que era falado pela Cíntia. Nesse grupo estava presente o professor Edinho Amorim, responsável pelas aulas de Educação Física, Matemática e Educação Ambiental, que ficou super interessado no assunto. Após terminarmos a palestra, o professor Edinho se propôs a chamar os alunos para no dia seguinte vir preparar a composteira. No fim, ficou decidido que faríamos atrás da escola, mas que compraríamos uma caixa d'água, pois assim ela não se contaminaria com o solo molhado pela fossa.

Quando finalizamos voltamos para a casa da Camila, em Manaus, no caminho viemos conversando com a Cíntia sobre aquela experiência, enquanto eu registrava 
em vídeo, para depois incluir essas falas numa montagem para o relatório final do projeto. Fomos descansar, com planos de no dia seguinte sair mais cedo, a fim de evitar o caótico trânsito.

\section{SEGUNDO DIA: MONTAGEM DA COMPOSTEIRA}

Na manhã seguinte partimos um pouco mais cedo e paramos em uma loja em Manaus, para comprar a caixa d'água e mais alguns materiais necessários, entre eles uma torneira, de onde sairia o composto orgânico líquido produzido pela composteira, e tintas. Chegamos na escola Chico Mendes, que se preparava para a festival Folclórico $^{12}$ que se realizaria naquele dia, e alguns estudantes e o professor Edinho nos aguardavam. Apareceram também moradores locais para verificar o que seria feito e um deles ajudou no processo. Começamos a separar grupos para começar a limpar o terreno enquanto algumas crianças faziam pinturas na caixa d'água

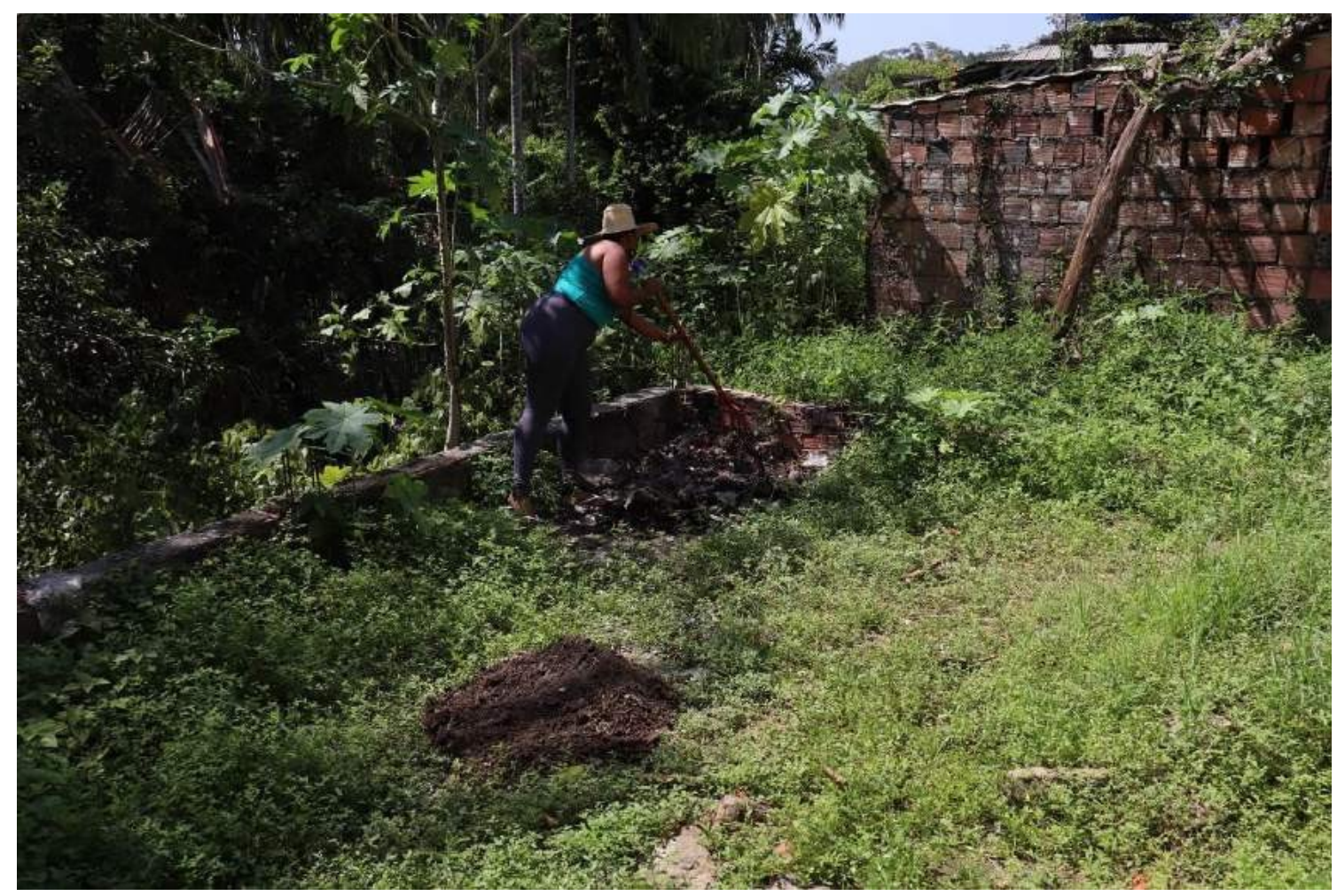

Fig. 6: Terreno antes da limpeza

Assim, todos os presentes, moradores locais e crianças da escola e professores, participaram de todos os processos. Enquanto isso, na escola preparavam comidas

\footnotetext{
${ }^{12}$ Festa Folclórica realizada todos anos pela Escola Chico Mendes, com apresentações culturais e venda
} de comidas e bebidas em barracas. 
que seriam vendidas no festival folclórico que aconteceria mais tarde naquele dia, e todos estavam bem animados. Fazia muito calor, era necessário que usássemos chapéu e também protetor solar.

Após o processo de limpeza do terreno, iniciou-se a plantação de uma hortinha. Concomitante, as crianças presentes faziam pinturas na caixa d'água, enquanto outras pintavam a parede próxima.

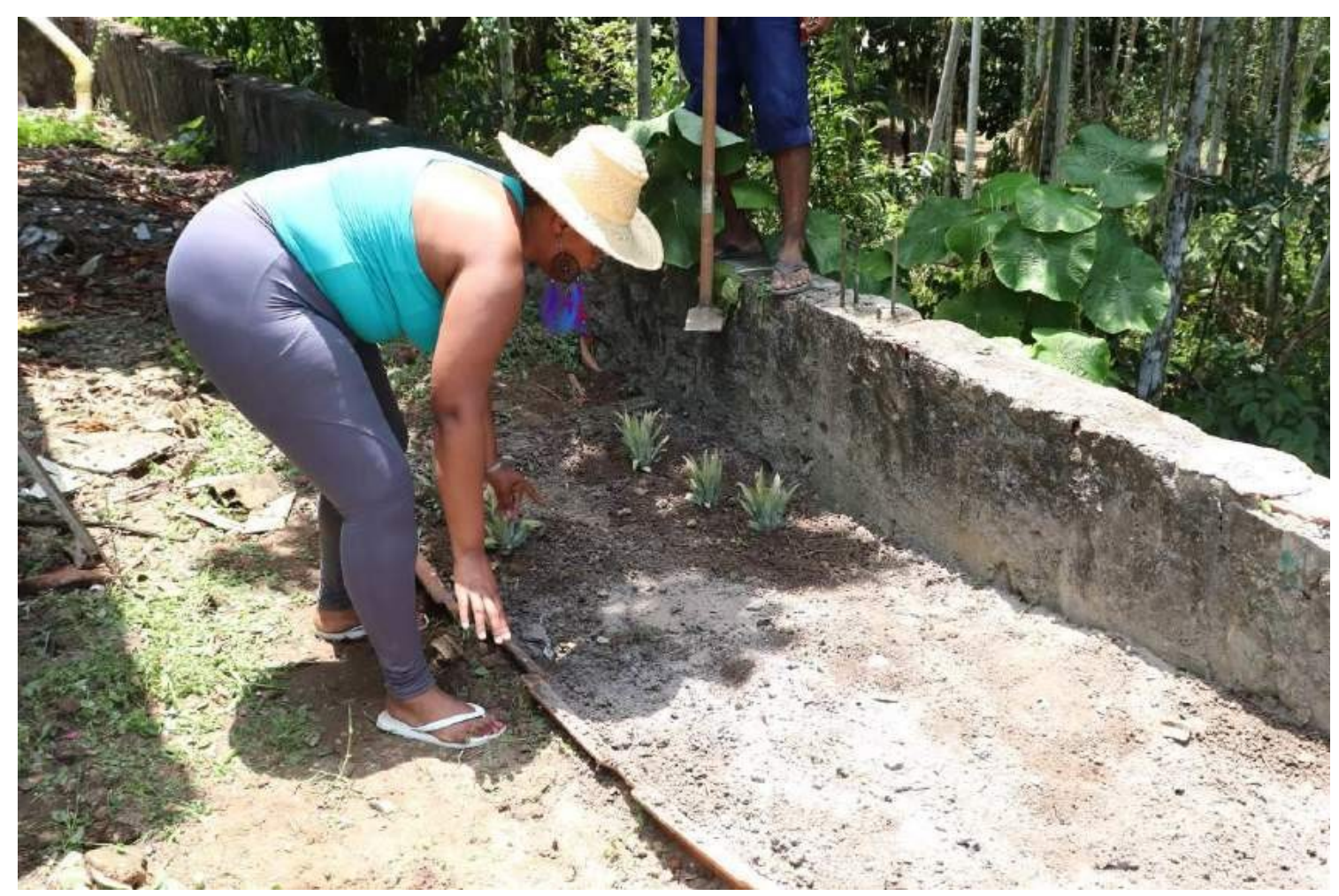

Fig. 7: Cíntia preparando a horta

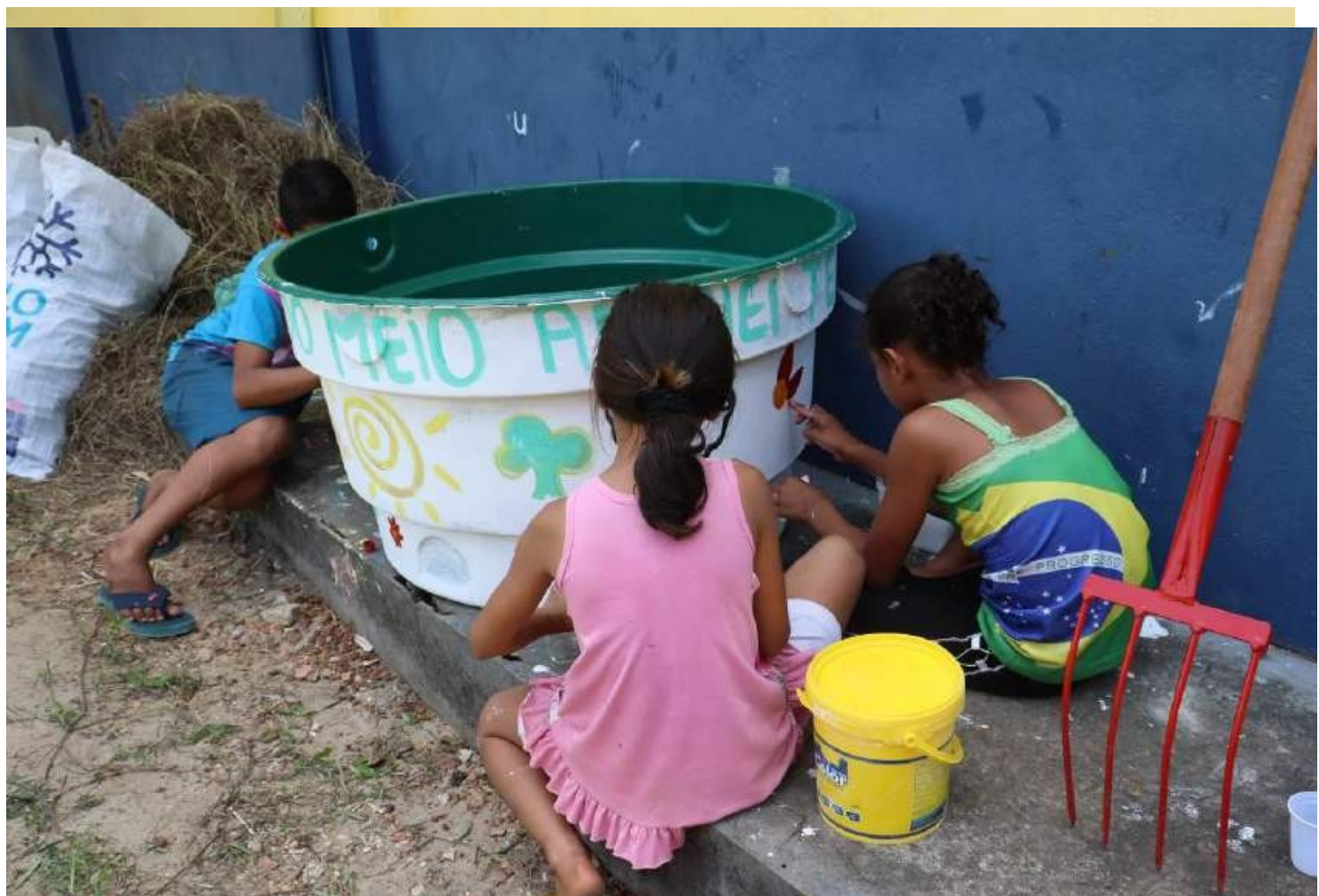


Fig. 9: Crianças pintando a caixa d'água

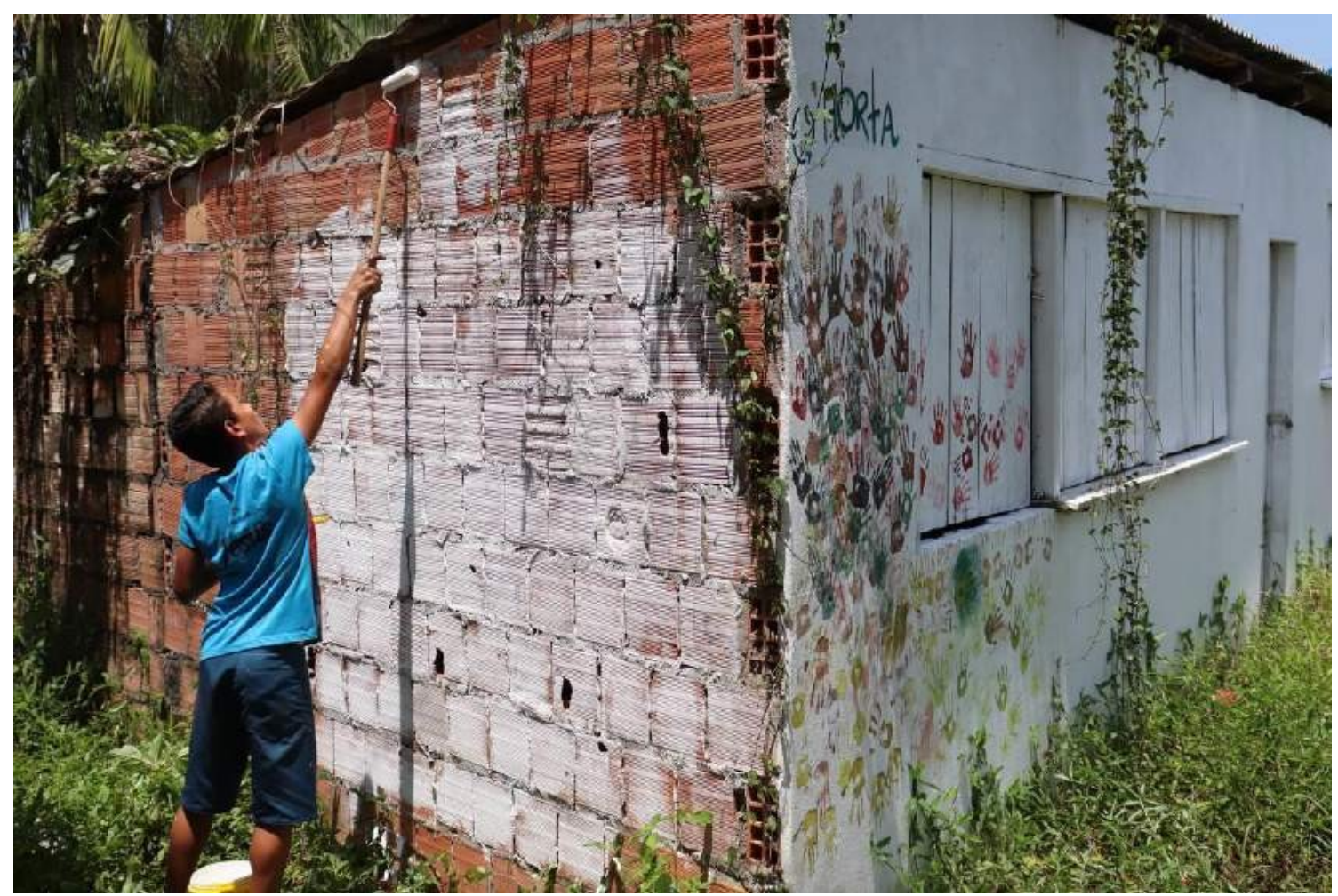

Fig. 10: Pinturas na parede

Com o terreno limpo e uma hortinha feita, os moradores conseguiram uma bananeira que foi plantada próxima a fossa, a fim de conter a contaminação do solo, já quea bananeira é uma planta que absorve bem a água no solo, servindo para drenálo. Cintia ainda fez algumas pinturas na parede para demarcar que a "Revolução" havia passado naquele local - além de diferentes localidades de Florianópolis, de Foz do Iguaçu (PR), do Rio de Janeiro (RJ), de Macaíba (RN), agora Iranduba recebia mais uma replicação da TS do PRB. 


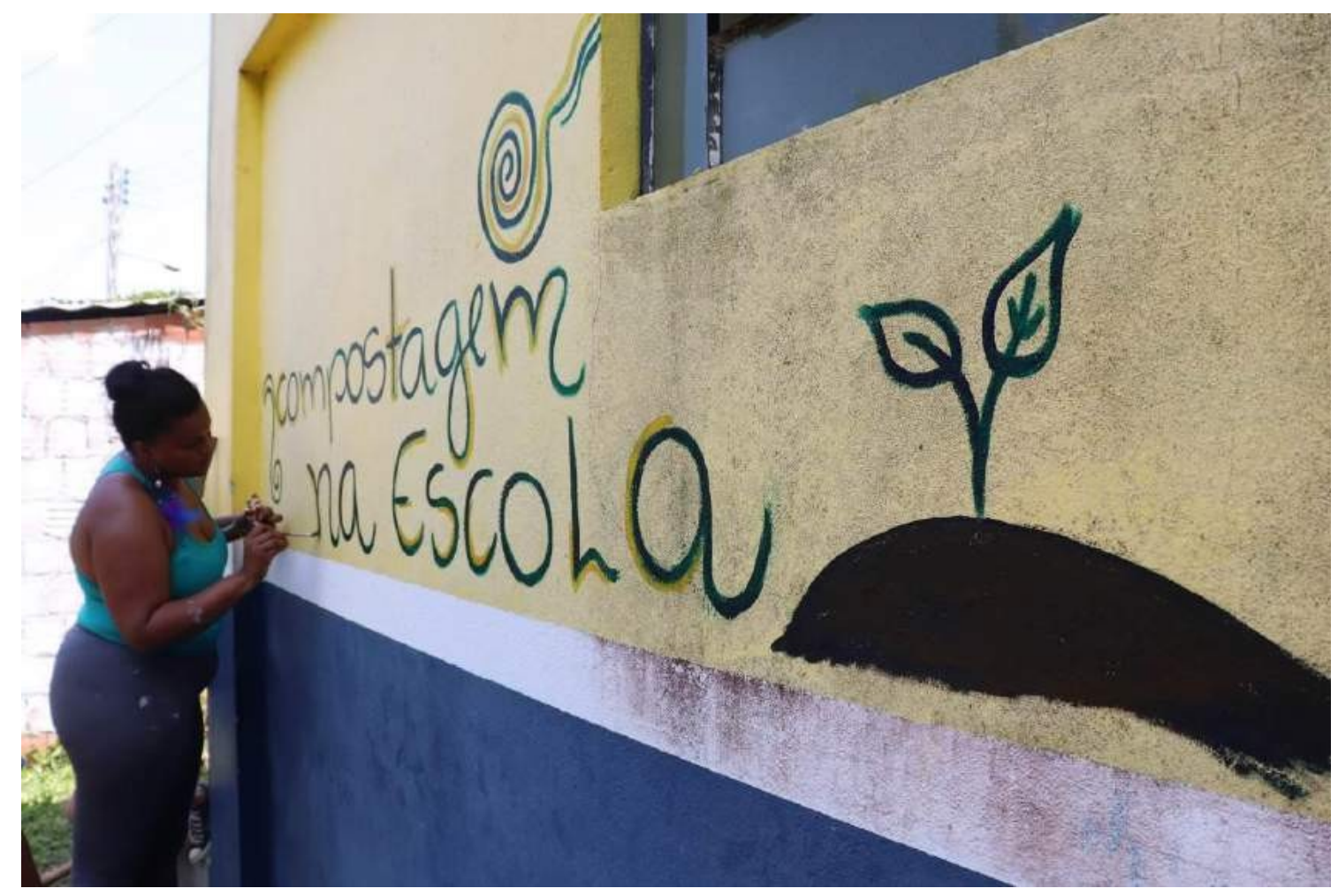

Fig. 11: Cíntia escrevendo "Compostagem na escola"

Após a secagem da caixa d'água, Cintia e Edinho fizeram furos na caixa d'água para que o ar pudesse passar e as bactérias aeróbicas pudessem fazer o trabalho de decomposição. Então, colocaram a torneira, responsável pela drenagem do composto, para então depositar a caixa no local escolhido. 


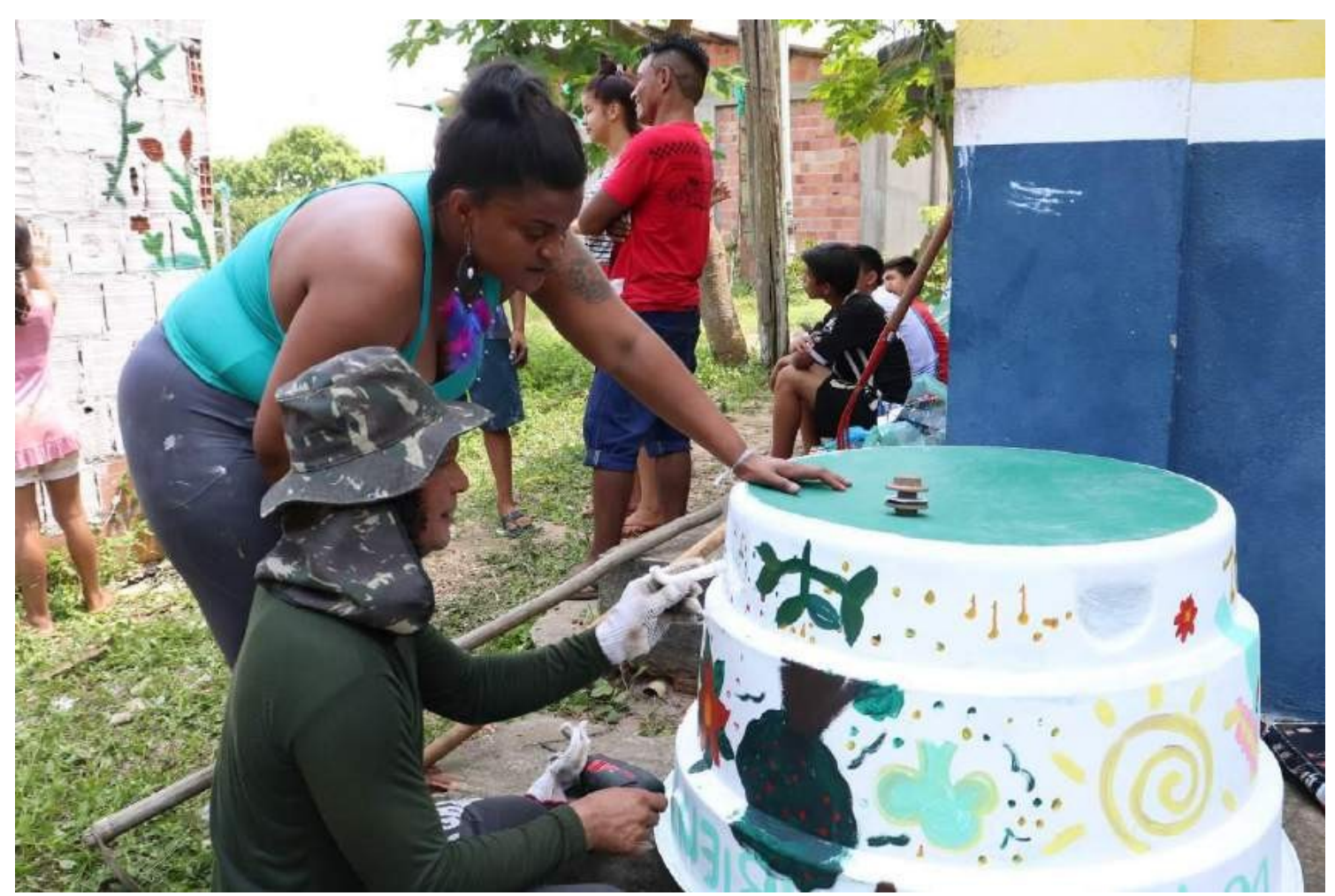

Fig. 12: Professor Edinho e Cíntia fazendo furos na caixa d'água

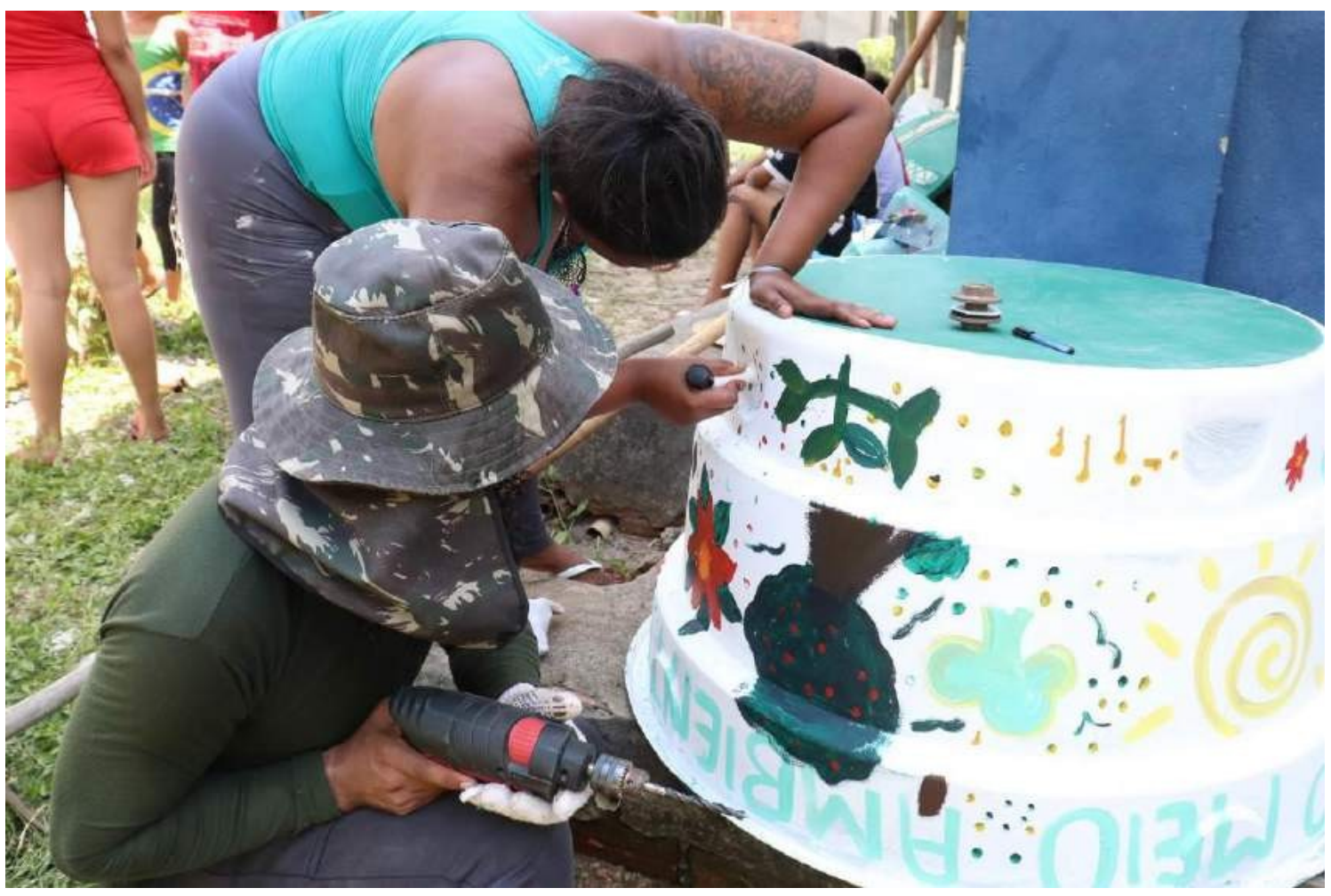

Fig. 13: Inserindo a torneira 


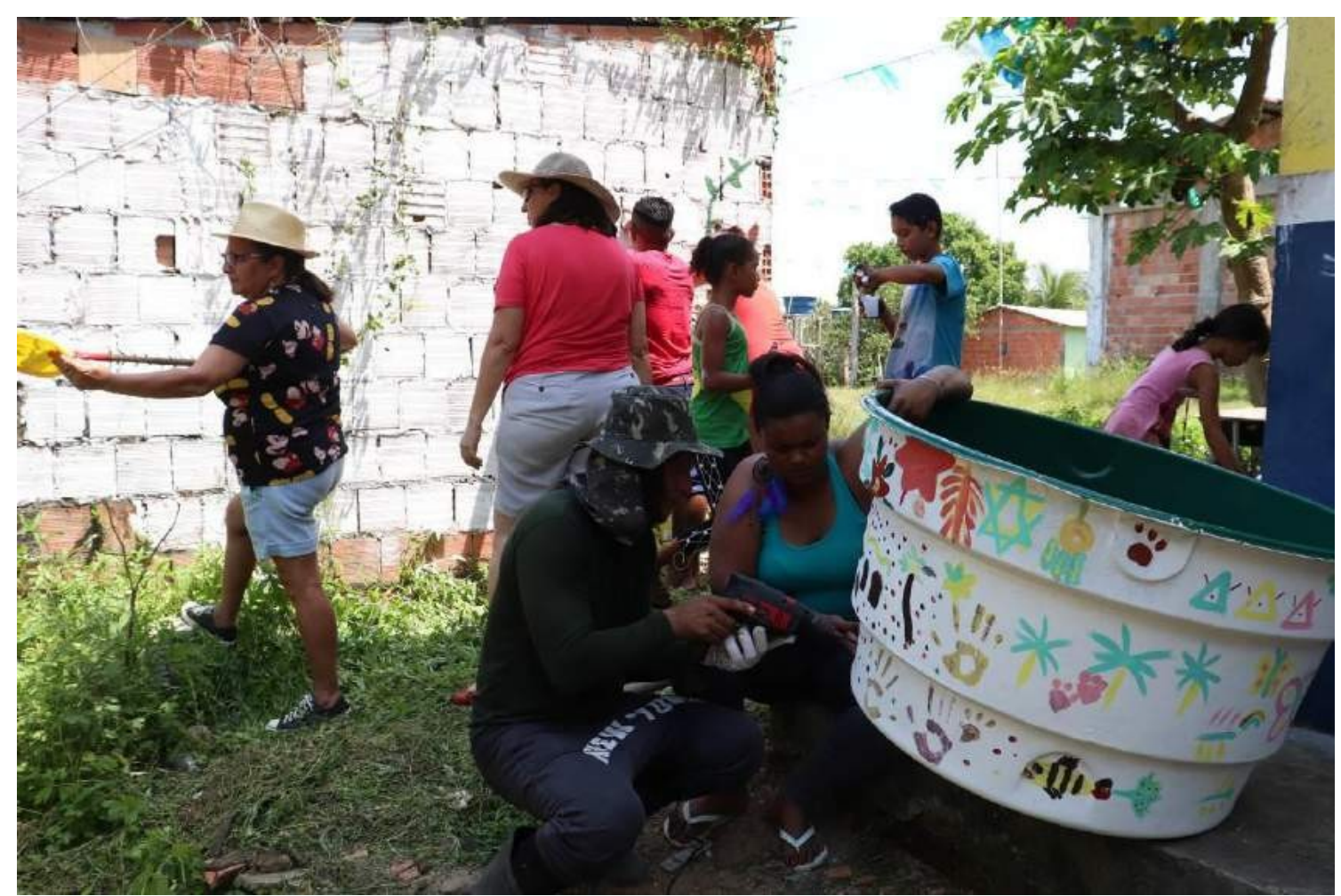

Fig. 14: Trabalho conjunto

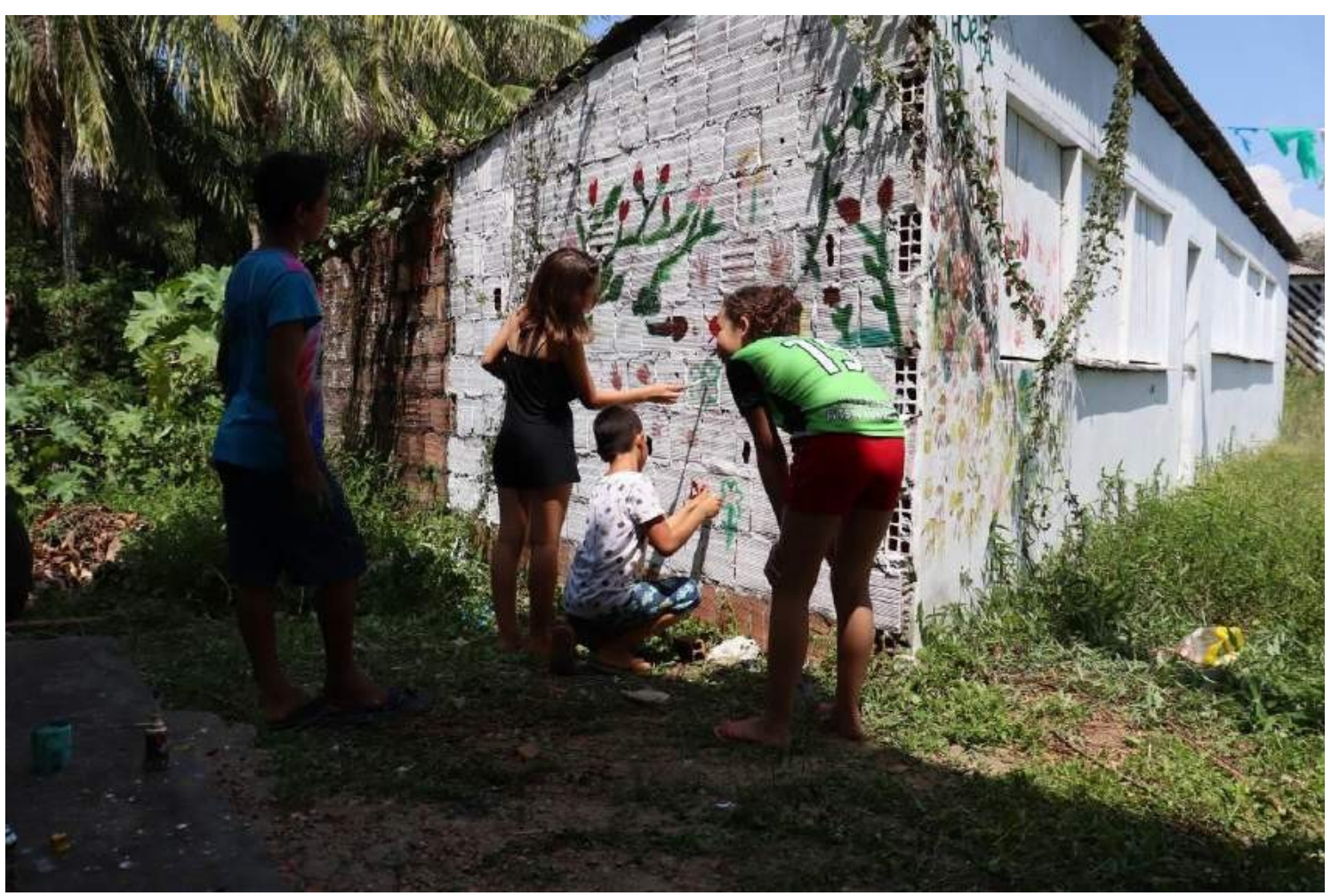

Fig. 15: Crianças finalizando a parede 


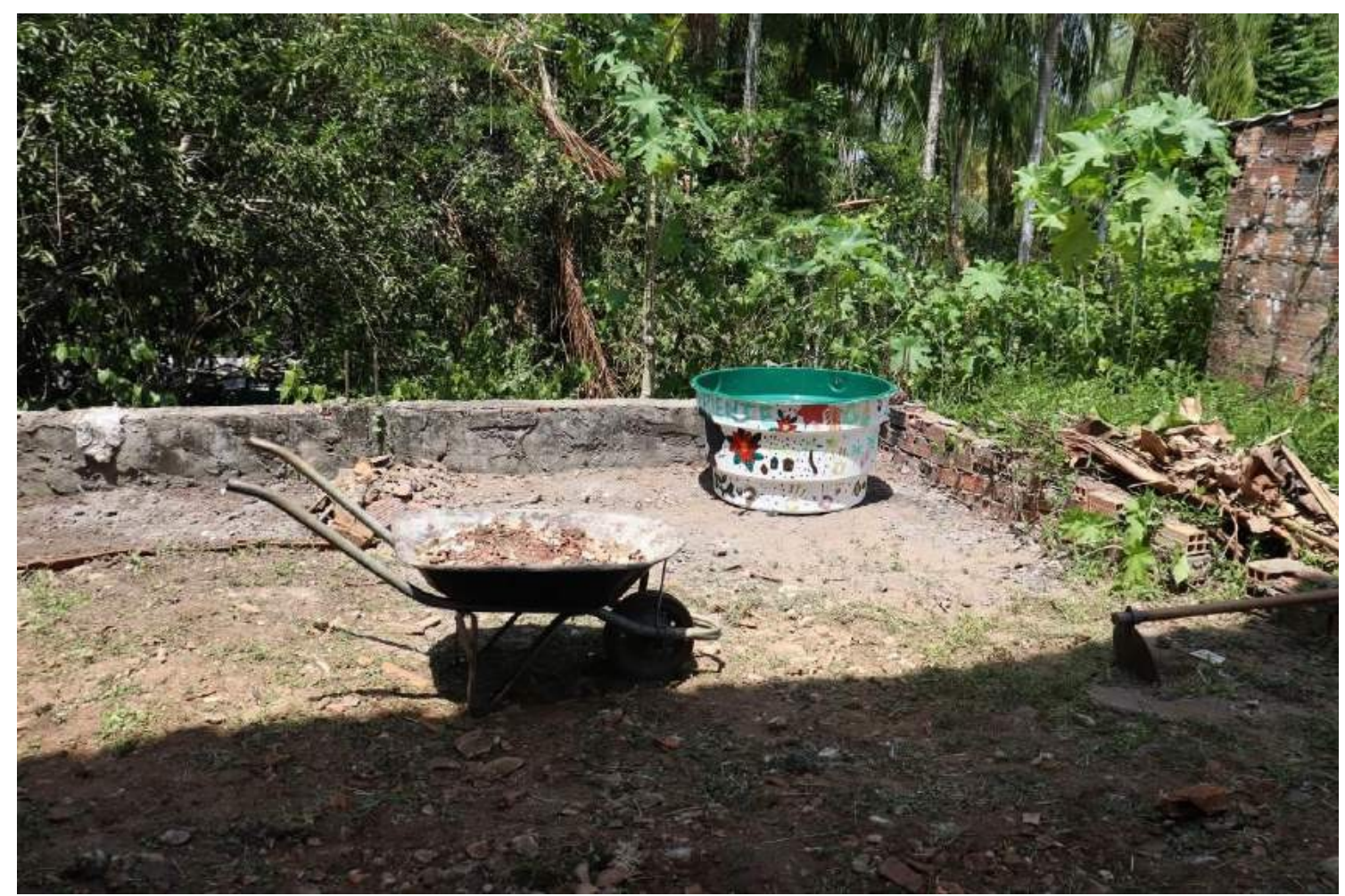

Fig. 16: Terreno limpo e caixa d'água no local escolhido

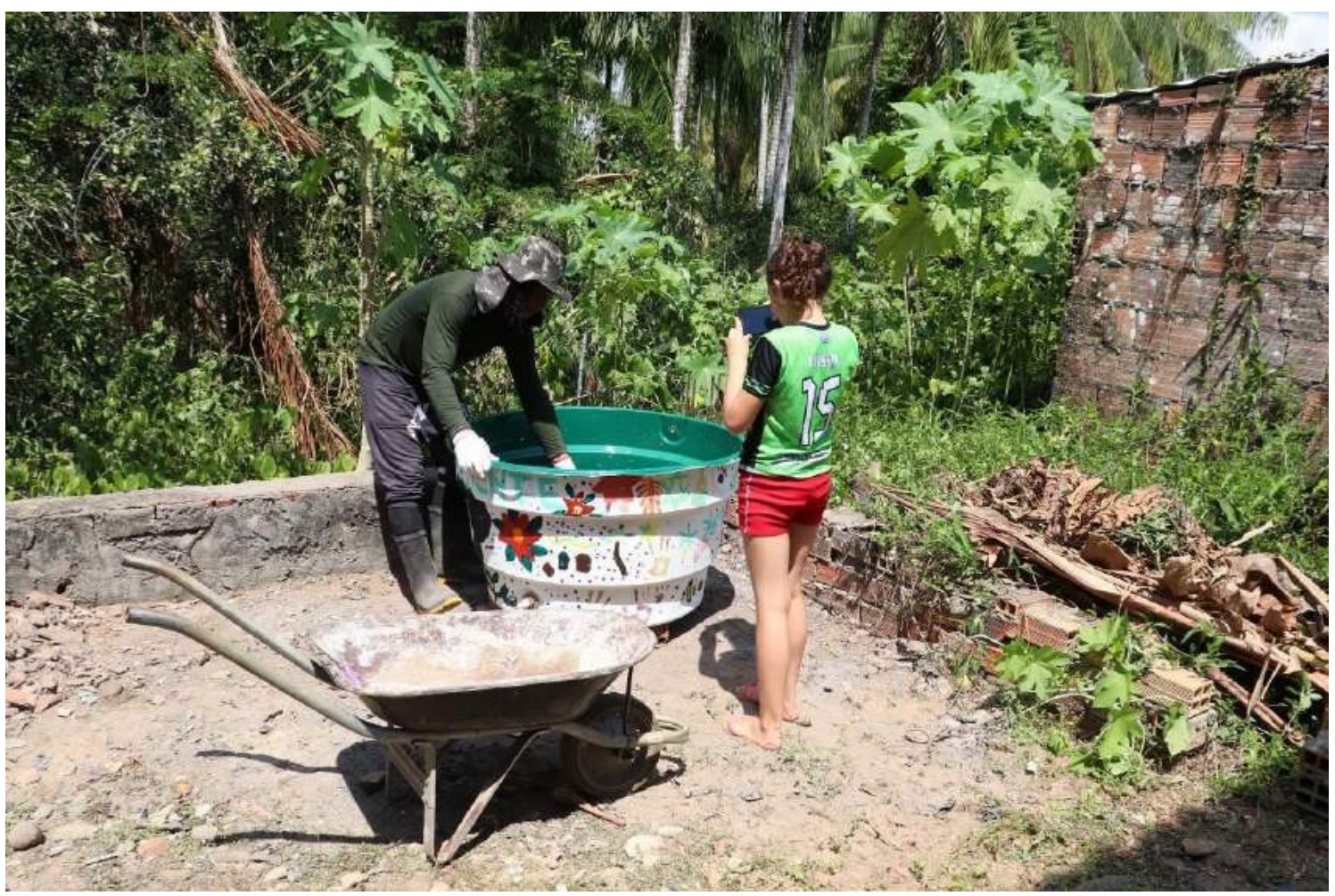

Fig. 17: Preparando material interno da composteira

Em seguida, foi preparada a composteira com os materiais estruturantes: a brita, o bidim, a serragem, o cepilho e a palha, que foi recolhida de locais próximos. Nesses momentos algumas crianças registravam o processo em seus celulares para 
posteriormente

poder repetir em outras composteiras. Para "inaugurar" foi utilizado o resíduo orgânico dos alimentos que estavam sendo preparados para a festa: bolo de aipim, e outras receitas locais. Nesse momento Cíntia explicou como seria depositado o material orgânico e quais seriam os próximos passos para a alimentação da composteira. Por fim finalizamos o trabalho e todos estavam muito satisfeitos com o resultado final.

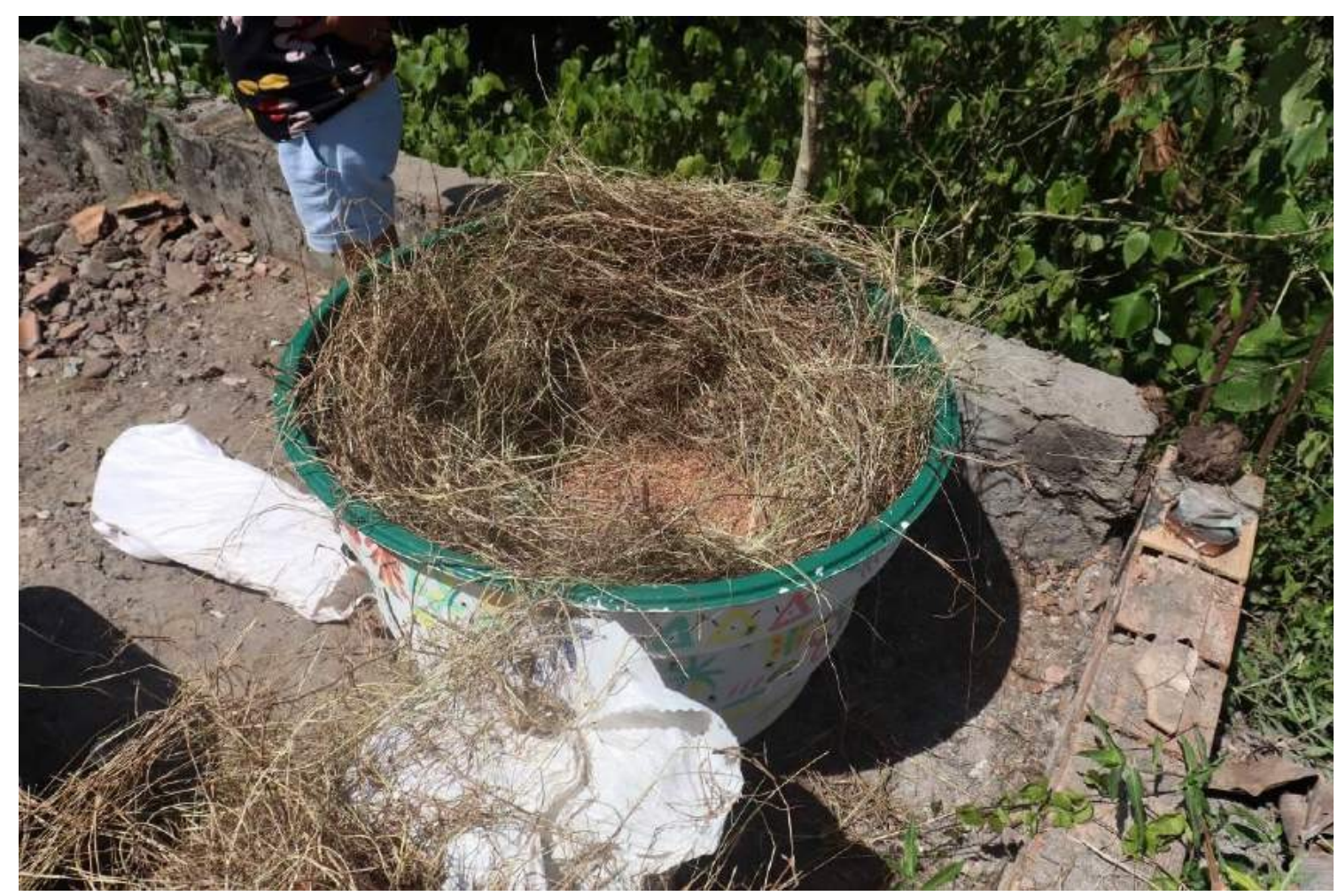

Fig. 18: Composteira com os materiais estruturantes 


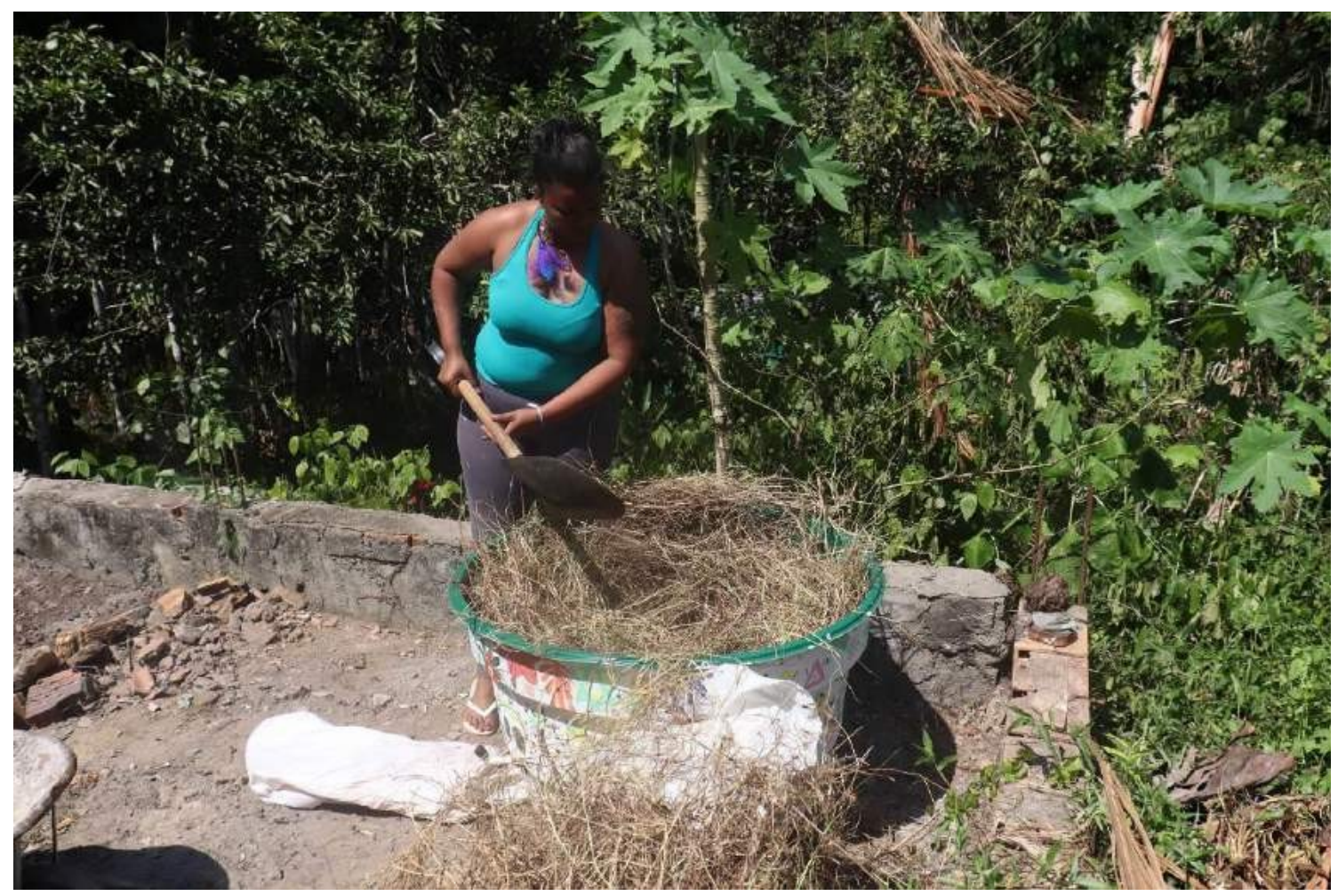

Fig. 19: Cíntia colocando os materiais

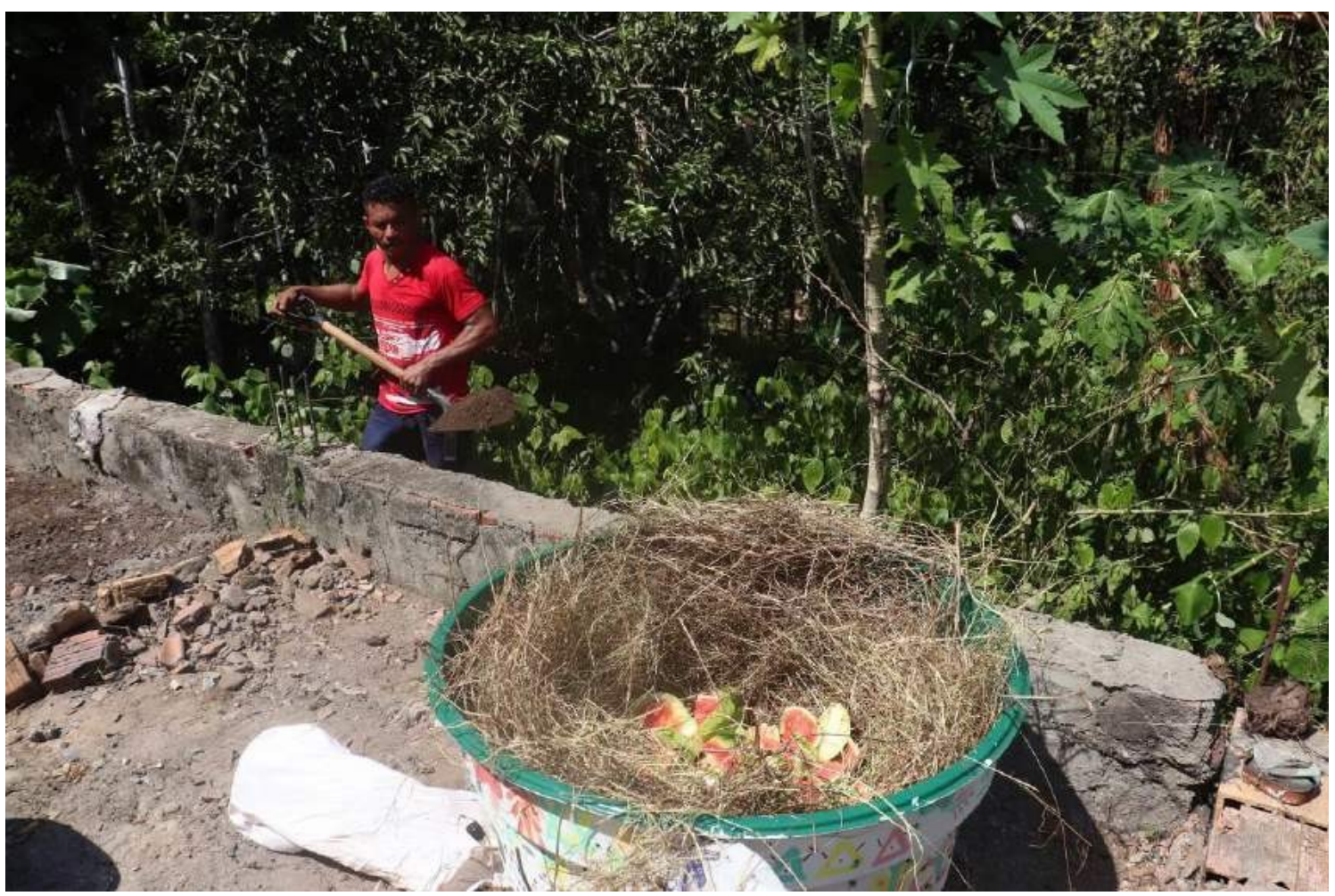

Fig. 20: Com os resíduos orgânicos 


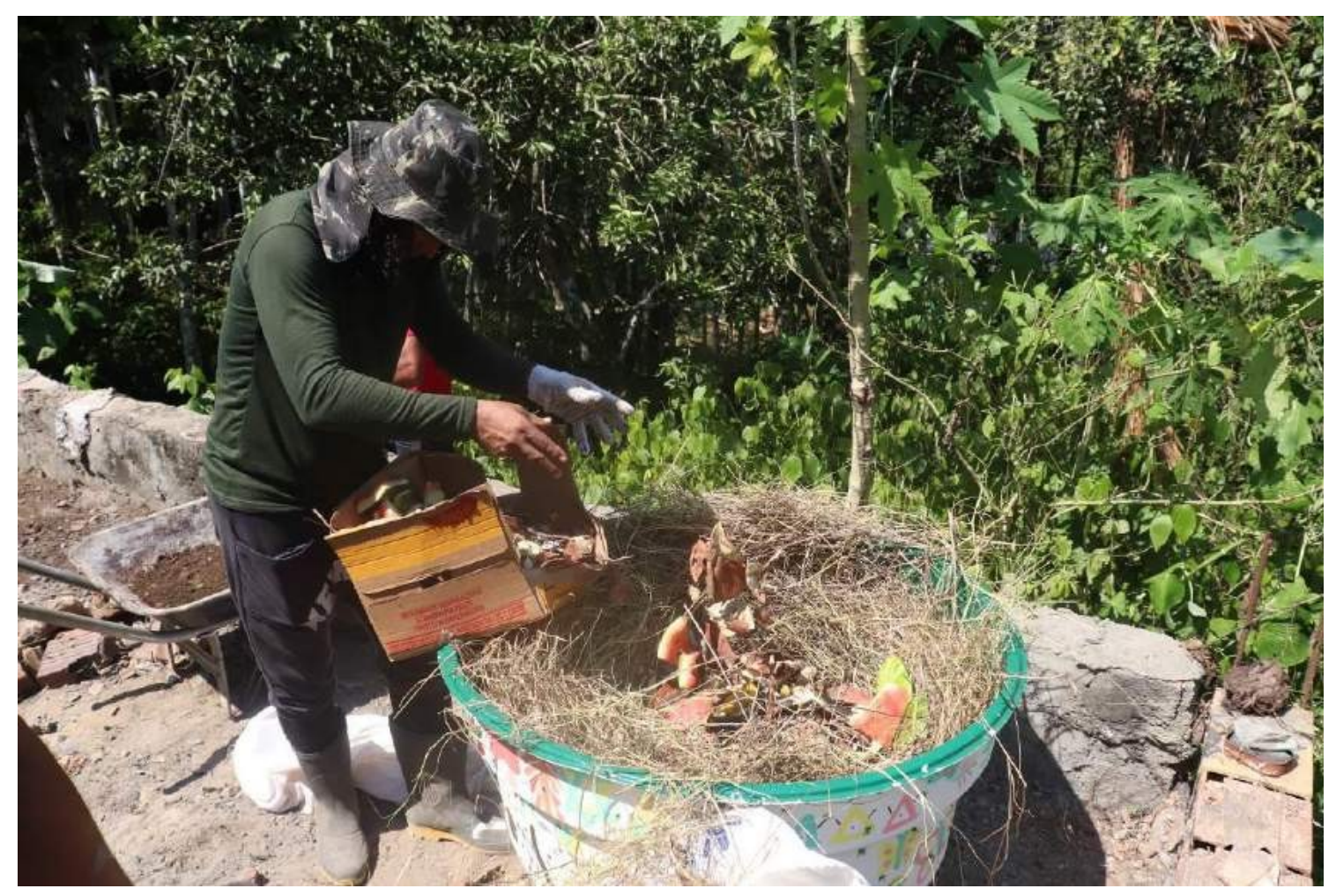

Fig. 21: Resíduos orgânicos sendo depositados pelo professor Edinho

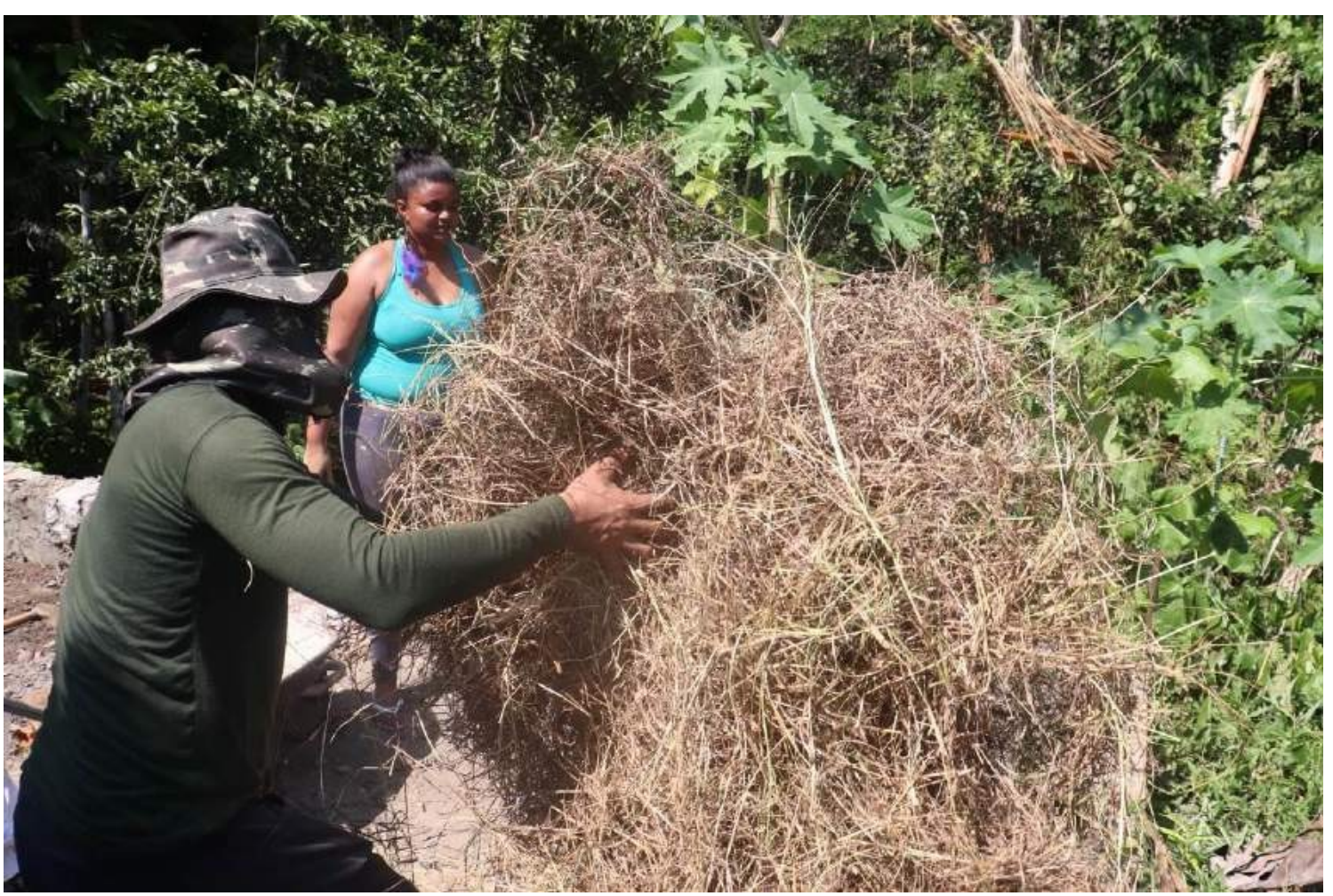

Fig. 22: Colocando a palha 


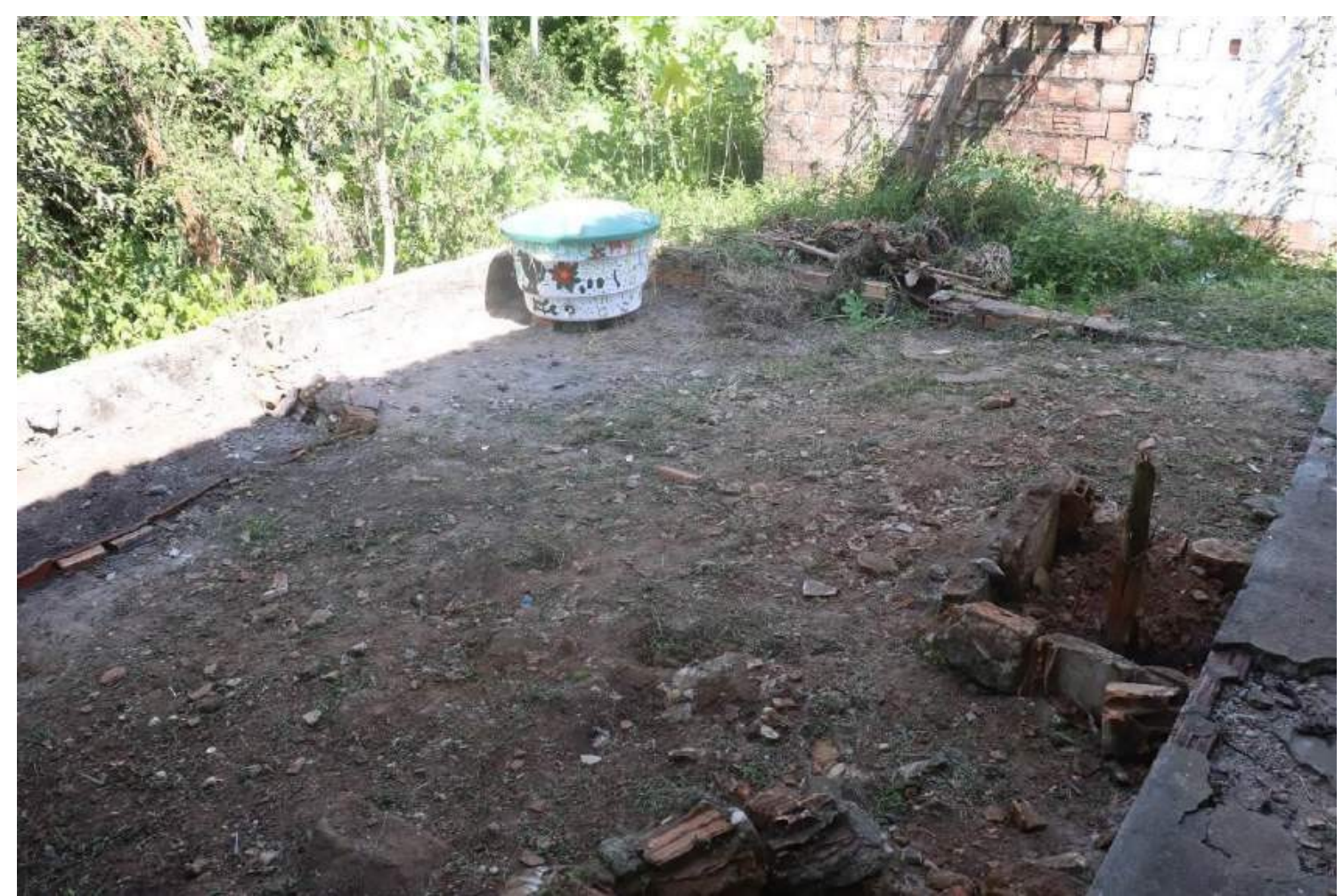

Fig. 23: À direita a bananeira plantada e no fundo a composteira,como ficou.

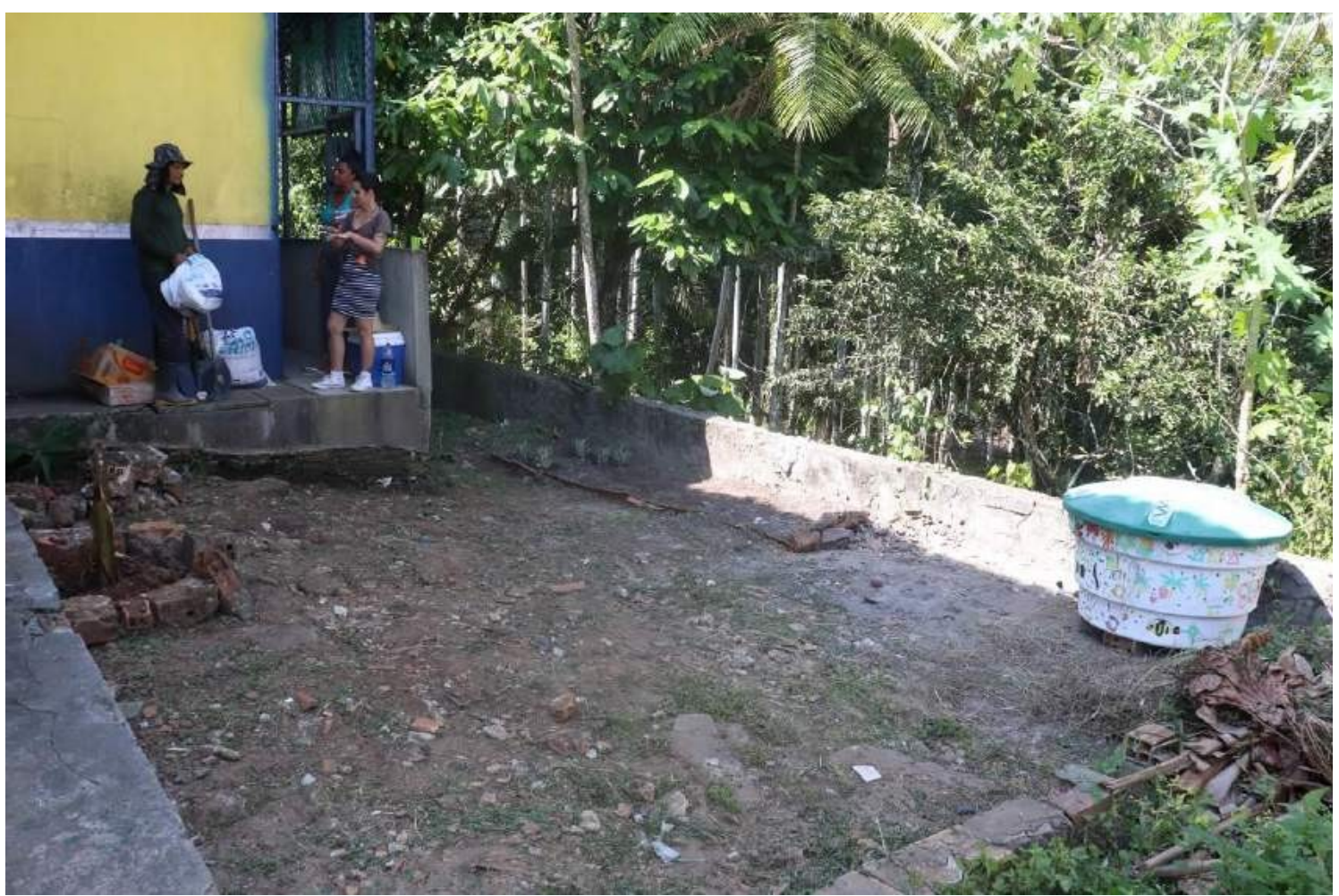

Fig. 24: Resultado visto de outro ângulo, com hortinha ao fundo à direita 


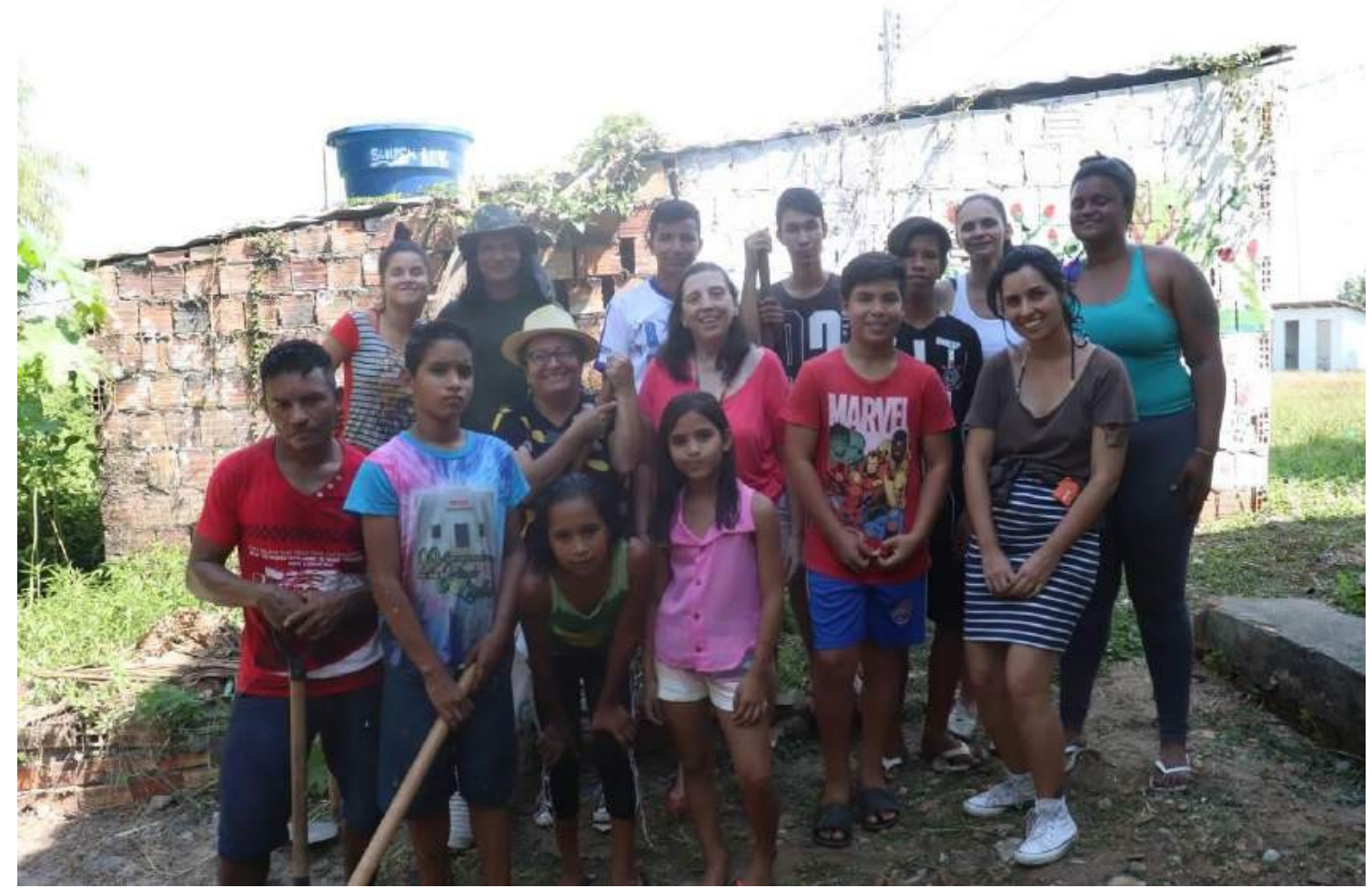

Fig. 25: Participantes da empreitada

Após finalizarmos, fomos convidados a compartilhar o almoço ali na escola. Haviam preparado uma canja de galinha para todos que estavam trabalhando tanto nos preparativos do festival, quanto no mutirão para a construção do "Compostagem na Escola $^{13}$ ". Agradecemos a todos pelos momentos passados, e todos estavam muito felizes. Estávamos muito cansadas e fomos embora logo depois do almoço.

\section{REFLEXÕES SOBRE O TRABALHO FOTOETNOGRÁFICO}

Quando fotos são escolhidas para "representar" um determinado trabalho, uma série de fatores são pensados. As fotos aqui escolhidas seguem a linha da ordem cronológica da viagem que, por sua vez, seguem a ordem do relato de viagem. Juntamente, as legendas procuram reforçar o texto escrito que narra como foi realizada a etnografia. No texto "'Ver' e 'dizer' na tradição etnográfica: Bronislaw Malinowski e a fotografia" de Etienne Samain (1995), encontramos considerações apontadas no que diz respeito ao trato de Malinowski com a fotografia em relação ao texto. Uma delas "diz respeito à concepção dos papéis globais que, para ele, a fotografia há de desempenhar com relação ao texto" (Samain,1995). Ao reler o conjunto das legendas que Malinowski

\footnotetext{
${ }^{13}$ Nome do projeto de Educação Ambiental escolhido pelos estudantes para ser implementado na Escola Chico Mendes.
} 
deu às suas fotografias, presentes nas obras acima referidas, descobre-se que alguns dos verbos usados para designar essas funções são claramente indicativos. Alguns exemplos são os verbos "to ilustrate" (ilustrar), "to see" (ver), "to show" (mostrar) e "to represente" (representar), no sentido que a fotografia seria uma amostragem, uma demonstração, to note (observe bem). E ainda sobre legendas:

Conforme Godolphim (1995), a foto na antropologia deve ter o objetivo de captar uma situação etnográfica e sociológica. Precisa ser capaz de transmitir as peculiaridades dessa situação para uma terceira pessoa ou grupo e comunicar da melhor maneira possível a interpretação que o pesquisador pretende demonstrar. Ainda de acordo com Godolphim (1995), o acréscimo de uma legenda, ou de um texto à imagem não é a única maneira de compreender a interpretação proposta pelo pesquisador, a fotografia em si possui uma linguagem narrativa que une a imagem ao tempo ao exibir uma determinada disposição de elementos que a constituem. Por sua vez, a palavra materializada em legenda ao agregar-se a uma imagem, pode tanto delimitar a interpretação do receptor da fotografia como ampliar seus significados isolados, criando uma relação de complementaridade (Pietroforte, 2010). (Soilo, 2012).

Outro debate presente na questão das análises das imagens e também no pós campo é sobre o "estando lá" e o "estando aqui". O antropólogo Roberto Cardoso de Oliveira, ao analisar a escrita do trabalho de campo, lembra desses dois momentos evidenciados por Geertz em Vidas e Obras (2005). Nele, Geertz define o "estando lá" como o estar em campo e o "estando aqui" que seria no seu gabinete, onde pode-se refletir com seus colegas universitários para a escrita dos textos (Cardoso de Oliveira,1996). A mesma analogia pode ser feita sobre a utilização das fotografias, em que se verifica cada imagem e suas interações, e assim busca-se nas reflexões dos textos, nas conversas com os colegas e os possíveis usos para esse material.

Nesse momento "estando aqui" pude conferir como foi registrado toda movimentação em torno daquela composteira e no que foi focado cada imagem, cada detalhe. E por ser uma movimentação rápida, em que o olhar não conseguia acompanhar todos os detalhes, em alguns momentos meus colegas chamavam "vem cá fotografar isso", "pode ser interessante", ou "grava essa conversa", "essa explicação". Então, por se tratar de um vídeo ligado a um projeto, muitas vozes eram ouvidas, para além da minha percepção ou daquilo que eu acharia interessante. Se com meu caderno de campo pude descrever cada detalhe do processo, com as imagens pude conferir meus olhares da colaboração dos colegas também. Assim, percebe- se como pode variar a escolha das imagens e o que queremos representar com ela. Como exemplo, dicilmente se vê as socializações presentes nesse momento, 
onde a maior preocupação era captar o processo de construção da leira, mas separando outras imagens é possível ver as interações entre os participantes, como na figura 26.

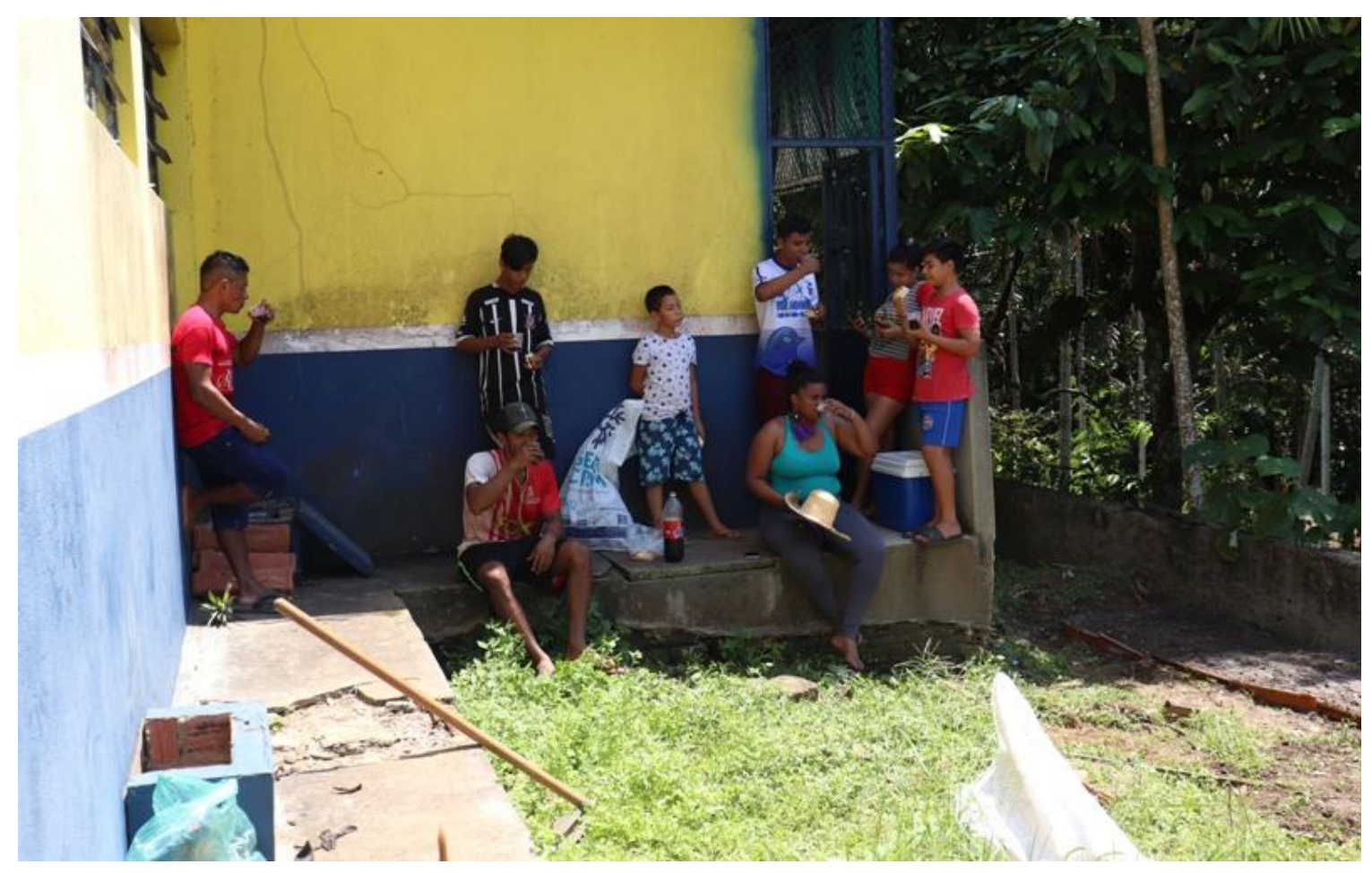

Fig. 26: Momento de descanso e refrescamento entre trabalhos

Uma questão que não implica somente uma escolha, é quando pensamos no que podemos ou não registrar. Como relatado na etnografia, um processo difícil foi o registro das crianças. Como disse anteriormente, fui alertada pela minha colega Caroline dos possíveis problemas éticos envolvendo a captação de imagens das crianças, e que o ideal seria fazer planos abertos em que não focassem rostos. Mas como era possível fazer isso numa escola? Inevitável que alguns momentos alguns rostos apareceriam, e que teriam que ser escondidos depois, eu pensaria como poderia trabalhar editando a fotografia.

Crianças são vistas como uma população vulnerável, e a legislação brasileira que normatiza a ética na pesquisa, ainda que tenha sido flexibilizada nos últimos anos para se adequar as especificidades da pesquisa em ciências humanas, mantém restrições quanto a pesquisar com populações vulneráveis. Nosso projeto não tinha 
sido registrado na Plataforma Brasil e nem submetido o comitê de ética da Universidade, exatamente porque não implicava em riscos para os pesquisados (ou pesquisadores, pois a legislação também serve como uma garantia aos pesquisadores de que não serão processados no futuro). Não usamos formulários de consentimento informado. Mas se fosse fotografar crianças necessariamente teria que ter a permissão dos pais ou das autoridades da escola onde estavam. Esse consentimento, das autoridades da escola, tínhamos de modo implícito pois nada nos foi dito que colocasse em duvida a captação

de imagens. Como podemos ver na figura 25 uma fotografia onde aparecem todas as crianças que estavam naquele momento participando. Pousam com consentimento porque querem fazer perceberem-se como participantes de todo os processos da oficina. Em outras fotos também é possível ver alguns rostos (como na Fig. 26), mas preferi me limitar a poucas nesse processo.

Então, foi desafiador mostrar o que acontecia sem necessariamente mostrar rostos e expressões, mesmo acreditando que essas expressões poderiam falar muito sobre o que estavam pensando esse público, como nas imagens 4 e 5 , onde estudantes aparecem de costas, ilustra bem esse ponto. Vemos Cintia apresentando o Projeto, mas não temos como ler a recepção da fala. Então deixaria para a descrição densa o que não pude descrever com imagens.

Outra questão pensada que por se tratar de um projeto de Extensão, existe uma demanda de que haja uma contrapartida para a comunidade. Além de fazer uma avaliação de tecnologia social, foi proposto de no produto final a realização de um material audiovisual tanto do campo em Florianópolis como da Oficina em Manaus. Pensando nas questões de compartilhamento e restituição estudados na Antropologia Visual, que foi construído o roteiro do vídeo a ser editado. Compartilhar envolve construir as imagens com os protagonistas e devolvê-las. Já a restituição segundo a antropóloga Carmen Rial, engloba o compartilhamento sem ele ser sinônimo, e no caso essa devolução pode ser feita não somente para esses protagonistas, como também em forma de entrevistas, artigos acadêmicos, palestras para publico não acadêmico (Rial, 2016)

Assim sendo, pensamos no roteiro do vídeo juntamente com Cíntia, que opinou sobre o que seria importante mostrar ou não. Durante a viagem conversamos com a equipe de Manaus e sugerimos fazer um banner com fotos da oficina, para que 
pendurassem na escola e divulgassem o trabalho realizado para a comunidade ausente. E foi feito um grupo de whatsapp para acompanhar o trabalho com a composteira, onde o professor Edinho envia fotos de como os alunos estão continuando o trabalho e esclarece dúvidas com Cíntia. Também nesse momento posterior à visita e instalação da composteira, as fotos tem tido um papel importante, mostrando, representando, permitindo que se veja, e especialmente, incrementando as trocas.

\section{CONSIDERAÇÕES FINAIS}

Retomando a pergunta inicial e vista no decorrer deste artigo, muitos fatores se apresentaram para ser levados em consideração no que diz respeito ao uso da fotografia em trabalho de campo, seja na parte metodológica ou mesmo técnica. No entanto, como reflete o antropólogo Alberto Groisman:

\footnotetext{
“A imagem não é só objeto, representante legítimo de um apropriar-se, mas ela se converte em experiência e é incluída densamente no que estou chamando aqui de processo, ou seja, um desdobramento articulado de pensamento e ação que constrói e reconstrói num continnum uma experiência específica" (Groisman, 2006).
}

Após as reflexões em campo presentes nesse trabalho, poderia enumerar vários momentos onde percebe-se a conversão em experiência, pois para fazer imagens é necessário uma inserção em campo, uma familiaridade com a câmera, com aquilo que se pretende fotografar, com os usos que se pretende fazer das imagens, etc.

Então, posso destacar alguns pontos analisados:

- Técnico: A câmera a ser usada deve ser levada em consideração, assim como todos os artefatos necessários para que a imagem saia de acordo com o esperado. A escolha aparentemente apenas técnica de que se uma imagem será feita com a câmera na mão ou usando o tripé tem impacto tanto no formato do trabalho que resultará, assim como nas relações entre fotógrafa e os que são fotografados. E mesmo o manuseio da câmera pode se converter - se em uma experiência, pois aquela pessoa fotografada pode querer ver como ficou sua imagem, autorizando ou não a sua publicação, assim como as interações que se tem ao ser visto como a pessoa "com a câmera". Ou seja, escolhas técnicas são escolhas epistemológicas. 
- A boa distância: Há uma máxima na fotografia que diz que se uma foto não ficou boa é porque não se chegou suficientemente perto. No entanto, antropólogos têm mostrado que uma imagem panorâmica pode falar muito sobre o local estudado, então é um registro interessante de se incorporar nas pesquisas. Planos gerais ou panorâmicos são boas entradas no campo, pois não implicam em contatos interpessoais, mais difíceis de serem estabelecidos rapidamente e permitem que se localizem características gerais do lugar. Observar pequenos detalhes que a imagem capta e que pareceriam despercebidos ao olhar a primeira vista, sem o auxilio da imagem ajudam a que se possa analisar o local antes de uma entrada e de imagens mais próximas.

- Ética: Questões de ética sempre devem estar presentes, e isso para além da legislação que no Brasil opera de uma forma, e em alguns casos o pesquisador pode ser processado. De preferência sempre ter alguma autorização para realizar imagens, ainda que essa autorização não precise ser escrita. No caso de adultos, um simples consentimento pelo olhar pode ser suficiente para o antropólogo, ainda que por precaução seja interessante ter o consentimento informado por gravação da fala ou por escrito.

- Legendas: Elas articulam a informação com o texto, e sempre acabam acrescentando alguma informação além daquela imagem que é passada.

- Restituição: Por se tratar de uma pesquisa de extensão o fator restituição já havia sido pensando desde o início. Percebe-se que numa pesquisa etnográfica é um fator importante por considerar que o campo também interage com o pesquisador, portanto devolver os resultados da pesquisa para os pesquisados pode contribuir tanto para a construção da pesquisa em si como para posteriores, pois cria transparência daquilo que se está fazendo e mais credibilidade.

- Arquivo: Estar atento aos cartões de memória,se darão conta de armazenar todo material, assim como o tamanho de cada arquivo. Houve uma certa dificuldade de passar todas as imagens que foram utilizadas na monografia escrita anteriormente, assim fui obrigada a converter cada foto num tamanho menor para que não sobrecarregasse o documento. 
Enfim, por se tratar de uma etnografia fotográfica percebe-se que as questões se diferenciariam caso fosse uma cobertura jornalista, pois existe a diferenciação no fator "olhar". Um antropólogo faz uso da fotografia de acordo com as analises que vai fazer em campo, na fotoetnografia "pode-se construir textos imagéticos a respeito da cultura do outro, fazer construções descritivas e narrativas," (Achutti, 1997). Já o jornalista tem olhar para detalhes que só ele busca para desenvolver sua matéria, sem considerar muitos atributos de interações sociais. O exercício aqui realizado dá razão a quem aponta a importância da imagem para nossas etnografias, pois na antropologia:

\begin{abstract}
A fim de compreender as interações do homem com o espaço no qual habita, a antropologia pode se utilizar de recursos imagéticos para alcançar diferentes perspectivas acerca de estudos sociais. A fotografia pode se apresentar de modo conjunto com o trabalho de campo produzindo sentidos que superam a perspectiva meramente imagética ou textual integrando significações. (Soilo, 2012)
\end{abstract}

Sem dúvida, imagens produzem sentidos para a pesquisa, para as análises e interações no campo.

\title{
REFERÊNCIAS
}

ACHUTTI, Luiz Eduardo Robinson. Fotoetnografia: um estudo de Antropologia Visual sobre cotidiano, lixo e trabalho. Porto Alegre: Tomo, 1997.

BECKER, Howard S. Métodos de pesquisa em ciências sociais. São Paulo: Hucitec, 1993.

CARDOSO DE OLIVEIRA, Roberto. Olhar, ouvir, escrever. Aula Inaugural, p. 5-27, 1994.

MALINOWSKI, Bronislaw. Argonautas do Pacífico Ocidental. São Paulo: Abril. Cultural, 1978

CAIUBY NOVAES, Sylvia. 2013. “A construção de imagens na pesquisa de campo em Antropologia". Iluminuras, 13 (31):11-29.

CAMPOS, S.M.C.T.L. A imagem como método de pesquisa antropológica: um ensaio de Antropologia Visual. Rev. do Museu de Arqueologia e Etnologia, São Paulo, 6:275- 
286, 1996. .

GEERTZ, Clifford. A interpretação das culturas. Rio de Janeiro: Zahar, 2008.

and Vera Ribeiro.Obras e vidas: o antropólogo como autor.

Editora UFRJ, 2002.

GROISMAN, Alberto. Fotografia e fotografar: paradigmas, artefatos e artifícios sociais e relacionais. In: LENZI, Lucia H. C. et ali (org). Imagem: intervenção na pesquisa. Florianópolis: EdUfsc, 2006.

LOPES, M. B.; NOGUEIRA, R. J. B. NASCIMENTO, L. R. C. Políticas sociais e aglomeração rural do Lago do Limão - Iranduba/AM. Agenda Social. V.5, no2, mai/ago / 2011, p. 24- 47.

MALINOWSKI, Bronislaw. Os argonautas do Pacífico Ocidental. São Paulo: Abril Cultural, 1978.

PEREIRA, S. M; WIGGERS, R. Família e Gênero no Lago do Limão - Iranduba/AM. Relatório Final PIBIC/PAIC 2017-2018. Universidade Federal do Amazonas, 2018.

RIAL, Carmem Silvia de Moraes. (2016). Roubar a alma - ou as dificuldades da restituição. In: VAILATI, Alex, GODIO, Matias, RIAL, Carmen (org.). Antropologia Audiovisual na Prática. Florianópolis: Desterro, [Florianópolis]: Cultura e Barbárie, 2016.

. . Contatos fotográficos: 2. Manezinho: de ofensa a troféu.

Universidade Federal de Santa Catarina, Programa de Pós Graduação em Antropologia Social, 2001.

SAMAIN.1995. "'Ver' e 'dizer' na tradição etnográfica: Bronislaw Malinowski e a fotografia", Horizontes Antropológicos, n.2.

SOILO, Andressa Nunes. A Arte da Fotografia na Antropologia: o Uso de Imagens como Instrumentos de Pesquisa Social. Revista Habitus: revista eletrônica dos alunos de graduação em Ciências Sociais-IFCS/UFRJ, Rio de Janeiro, v. 10, n. 2, p.73-80, 
Dezembro. Disponível em: <www.habitus.ifcs.ufrj.br>. Acesso em: 16 de nov. de 2015.

Recebido: 14/10/2020

Aprovado: 08/12/2020 